\title{
COMPARATIVE ASSESSMENT OF HEALTH AND SAFETY IMPACTS OF COAL USE
}

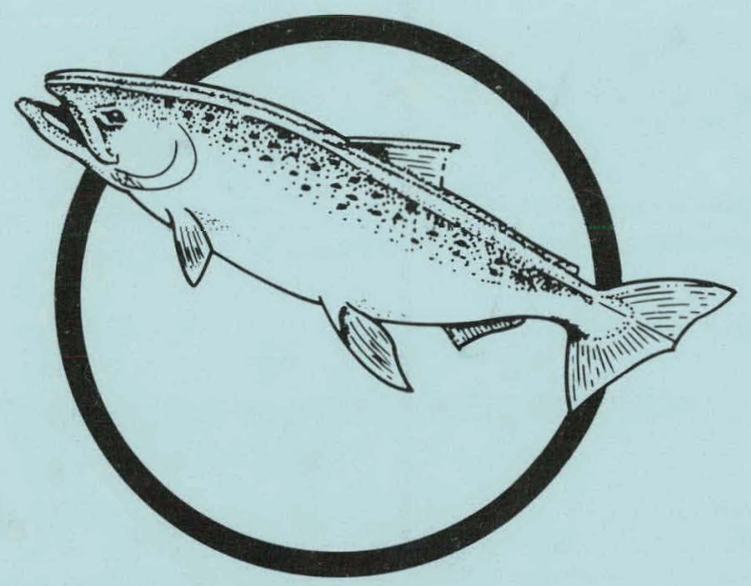

March 1980

\section{U.S. Department of Energy Assistant Secretary for Environment Office of Technology Impacts Technology Assessments Division}

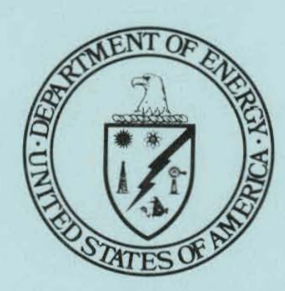




\section{DISCLAIMER}

This report was prepared as an account of work sponsored by an agency of the United States Government. Neither the United States Government nor any agency Thereof, nor any of their employees, makes any warranty, express or implied, or assumes any legal liability or responsibility for the accuracy, completeness, or usefulness of any information, apparatus, product, or process disclosed, or represents that its use would not infringe privately owned rights. Reference herein to any specific commercial product, process, or service by trade name, trademark, manufacturer, or otherwise does not necessarily constitute or imply its endorsement, recommendation, or favoring by the United States Government or any agency thereof. The views and opinions of authors expressed herein do not necessarily state or reflect those of the United States Government or any agency thereof. 


\section{DISCLAIMER}

Portions of this document may be illegible in electronic image products. Images are produced from the best available original document. 


\section{COMPARATIVE ASSESSMENT \\ OF HEALTH AND SAFETY \\ IMPACTS OF COAL USE}

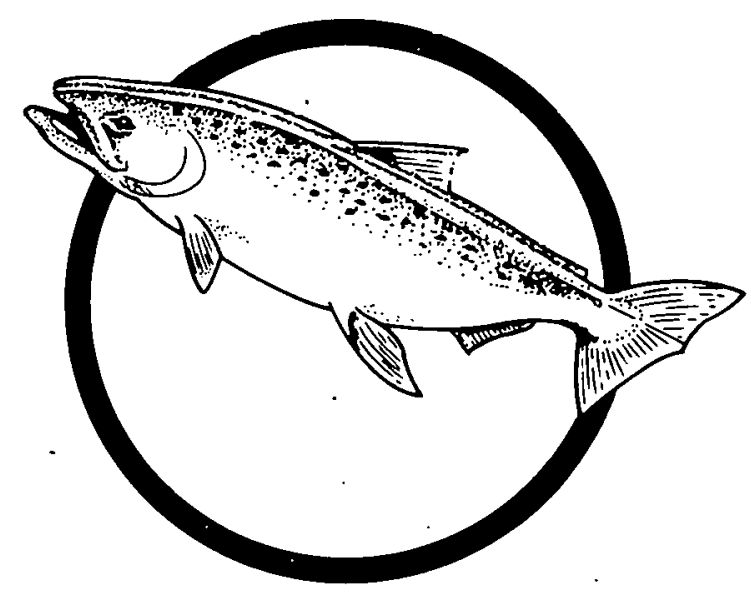

March 1980

\section{U.S. Department of Energy Assistant Secretary for Environment Office of Technology Impacts Technology Assessments Division Washington, D.C. 20545}

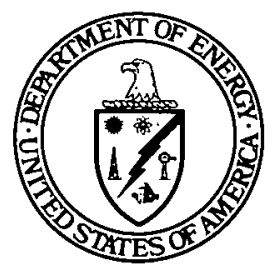


.1.

$-i$

Avallable from:

National Technical Information Service (NTIS)

U.S. Department of Comnerce

5285 Port Royal Road

Springfield, Virginia 22161

Price: $\quad$ Printed Copy: $\quad \$ 6.00$

- Microfiche: $\$ 3.00$ 
PREFACE

The Department of Energy was requested by the Office of Management and Budget "to provide a review in the fall of 1978 of the detailed environmental and health assessment on coal liquids and a. comparison of the use of these liquids with direct combustion and coal gasification. The assessment should detail, to the extent possible, the data and conclusions now known with respect to carcinogenicity, mutagenicity, toxicity, solid wastes, air and water emissions, and other health and environmental pollutants resulting from coal liquefaction."

The President's National Energy Plan as embodied in the National Energy Act encourages a shift from conventional oil and gas resources to synthetic fuels from coal. Technologies to convert coal to liquid and gaseous fuels are under development, with the active participation of the Department of Ener.gy. The development of coal conversion may involve significant health and environmental impacts of national, regional, and local natures. The potential impacts, in turn, are expected to influence the character, timing, and extent of the development.

The concise assessment presented in this report was performed to provide information on what health and environmental impacts might be anticipated from a policy encouraging coal liquefaction: What are the areas of uncertainty that need further research and evaluation? How does coal liquefaction compare with other alternatives of deriving energy from coal with respect to health and environmental impacts? 


\section{ACKNOWLEDGMENT}

This document was prepared by Dr. Eli Salmon of Resources for the Future under the sponsorship of the Assistant Secretaries for the Environment and for Energy Technology in the Department of Energy. The work was undertaken at the request of the Office of Management and Budget. The report has drawn upon many resources of information and findings prepared or presented by representatives of the Department of Energy, the Environmental Protection Agency, Argonne National Laboratory, Brookhaven National Laboratory, and Oak Ridge National Laboratory. The author is particularly grateful for the comments and suggestions of Dr. Leonard D. Hamilton, Head of the Biomedical and Environmental Assessment Division of Brookhaven National Laboratory, and his colleagues: Samuel C. Morris, Walter A. Sevian, Paul D. Moskowitz, and Sam Silberstein. The Brookhaven National Laboratory's Energy System Network Simulator energy-environmental process model, maintained by BEAD, was used to evaluate various energy system factors and emissions utilized in the evaluations of this report.

Dr. Stanley I. Auerbach, Director of the Environmental Division of Oak Ridge National Laboratory, was very helpful in providing a wealth of information and data necessary for the identification, evaluation, and comparison of the health and environmental impacts from various coal technologies. Dr. Auerbach also provided useful suggestions and comments on how to improve the draft report. -

Appreciation is also due to Dario R. Monti, Arnold J. Goldberg, and Charles Carter of the Department of Energy and to Dr. Surles of Argonne National Laboratory for their useful comments which were incorporated into the report.

The report is based on previous work of Dr. Eli Salmon, including "Health and Environmental Implications of Various Energy Systems," prepared under the National Energy Strategies Project of Resources for the Future, Inc., and "Potential Impacts from Increased Coal Utilization," prepared for the National Academy of Sciences.

A structural diagram of the organization, preparation, and review of the report is included as the appendix. 
EXECUTIVE SUMMARY $\ldots \ldots \ldots \ldots \ldots \ldots \ldots \ldots \ldots \ldots \ldots \ldots, v$

I INTRODUCTION $\ldots \ldots \ldots \ldots \ldots \ldots \ldots \ldots \ldots \ldots \ldots \ldots \ldots \ldots \ldots \ldots \ldots \ldots \ldots$

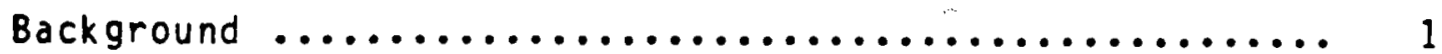

object ives $\ldots \ldots \ldots \ldots \ldots \ldots \ldots \ldots \ldots \ldots \ldots \ldots \ldots \ldots \ldots \ldots, r_{2}$

Basis for selection..............................? 2

Methodology $\ldots \ldots \ldots \ldots \ldots \ldots \ldots \ldots \ldots \ldots \ldots \ldots \ldots, 4$

How Good are the Data?........................... 5

Major Occupational Health and Safety Impacts $\ldots \ldots \ldots \ldots .6 .6$

Health and Safety Impacts on the General Public ......... 8

Environmental Impacts On Plants, Animals, Ecosystems,

and Property .................................... 9

Socioeconomic Impacts $\ldots \ldots \ldots \ldots \ldots \ldots \ldots \ldots \ldots \ldots \ldots . . . . .6$

II OVERVIEW OF COAL ENERGY TECHNOLOGIES $\ldots \ldots \ldots \ldots \ldots \ldots \ldots 11$

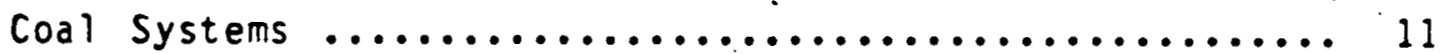

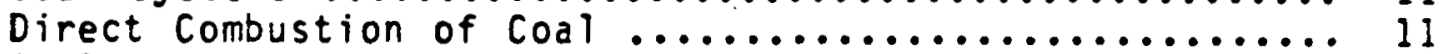

Coal Conversion .................................... 13

Coal Gasification ............................... 13

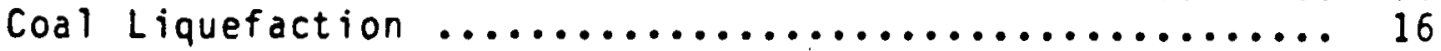

II SYSTEM CHARACTERISTICS OF MAJOR TECHNOLOGIES $\ldots \ldots \ldots \ldots 21$

IV MAJOR HEALTH AND SAFETY IMPACTS $\ldots \ldots \ldots \ldots \ldots \ldots \ldots \ldots \ldots . \ldots \ldots$

Occupational Health and Safety Impacts ............... 39

Health and Safety Impacts to the General Public ........ 46

Health Effects of Gases and Aerosols ........... 47

Impact from Coal Transportation................. 50

Impacts from Trace Contaminants ................ 51

Comparison of the Health Impacts from Various Systems ... 54

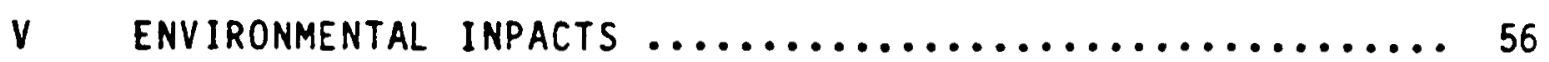

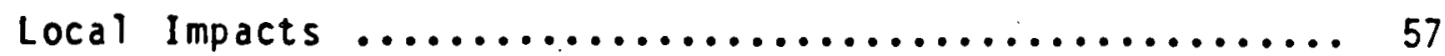

Comparison of the Impacts from Alternative Coal Systems.. 58

REFERENCES............................... 60

APPENDIX ..Structural Diagram of the Organization, Preparation, and Review of the Comparative Assessment of Health, Safety, and Environmental Impacts of Coal Use... 


\section{EXECUTIVE SUMMARY}

BACKGROUND AND OBJECTIVES

An analysis of United States and world energy supplies reveals that an imbalance, exists between present patterns of energy resources and energy consumption. The energy content of all domestic sources of conventional oil and natural gas is equivalent to about 2 percent of the energy contained in coal. However, these sources provide about 76 percent of current gross energy use versus about 18 percent from coal. A shift toward greater use of coal would bring about a better match between energy resources and supplies.

Increasing the use of coal to replace oil and gas consumption is considered beneficial for economic and political reasons. The evaluation of this report, however, is that the shift to coal can involve significant health, safety, and environmental impacts compared to those from 0 il and natural gas systems, which are considerably less adverse than. those of any coal energy system in use today. An evaluation and comparison of the potential impacts from the various alternative coal technologies would be useful to both governmental and industrial policy planners and would provide them with information relevant to a decision on assistance, incentives, and prioritization among the energy technologies. It is; therefore, the main objective of this report to review the key health, safety, and environmental impacts of some promising coal energy technologies and to compare them. 
METHODOLOGY

The report compares the potential health, safety, and environmental impacts from coal liquefaction with the following coal energy technologies, all of which may substitute for and compete for resources with coal liquefaction:

- Coal liquefaction :- solvent refined coal (SRC-II) process

- Atmospheric fluidized bed combustion (AFBC)

- Low-Btu gasification -- Lurgi process

- Medium-Btu gasification -- Lurgi process

- High-Btu gasification -- Lurgi process

- Conventional combustion with flue gas desulfurization (FGD)

Conventional combustion of coal with flue gas desulfurization is compared with other technologies, because 70 percent of all coal produced in this country is used in power plants to produce electricity. In the past, low-sulfur coals and tall stacks were used to meet the requirements of the Clean Air Act Amendments of 1970. The more restrictive Amendments of 1977 required improved emission controls. Flue gas desulfurization is considered to constitute the "best available control technology" (BACT) that will enable new utility and industrial boilers to meet the more stringent air pollution requirements. The other processes selected for analysis are representative of available processes.

of the foregoing six technologies, four result in the generation of electricity: low-Btu gasification (combined cycle), conventional and direct combustion, and SRC. The electricity so generated may be used directly or may be used in the residential or industrial sectors. Also, high- and low-Btu gas from coal and direct combustion processes may provide energy directly to these sectors.

The appropriate comparisons then depend on the efficiency of the entire cycle of source to end-use energy consumption and involve those additional residuals generated as the coal-based fuel (gas, liquid, or electricity) is transmitted to and used by the residential and industrial sectors. Accordingly, in this analysis, three separate sets of 
-comparisons are made for each of three end uses, i.e., direct residential use, commercial use, and electricity generation (see table). Four competing technologies may be used to generate electricity. In the residential sector, either electricity oenerated by one of these four processes or synthetic gas may be used. In either case, a quad of fuel will yield a different value of net energy to the user, the value will also be different for each of the industrial fuels. Therefore, a different quantity of each fuel is needed to generate 1 quad of end-use energy.

The health, safety, and environmental impacts associated with each technology and each end-use are evaluated in this report within the framework of complete energy source to end use systems. Coal exploration and mining, transportation, production of fuel, and distribution to. consumers are all examined.

Source to End Use Systems Examined

\begin{tabular}{|c|c|c|}
\hline End Use & $\begin{array}{l}\text { Conversion to Fuel } \\
\text { for Direct Use }\end{array}$ & Conversion to Electricity \\
\hline Residential Heating & High-Btu gas & $\begin{array}{l}\text { Low-Btu gas (combined cycle), } \\
\text { conventional combustion, } \\
\text { direct (fluidized bed) com- } \\
\text { bustion, coal liquids (e.g., } \\
\text { SRC) }\end{array}$ \\
\hline $\begin{array}{l}\text { Commercial and } \\
\text { Industrial or } \\
\text { Space Heating }\end{array}$ & $\begin{array}{l}\text { High-Btu gas, } \\
\text { Low-BTU gas, } \\
\text { FBC }\end{array}$ & $\begin{array}{l}\text { Low-Btu gas, conventional } \\
\text { combustion, } F B C\end{array}$ \\
\hline $\begin{array}{l}\text { Direct Power } \\
\text { Generation }\end{array}$ & & $\begin{array}{l}\text { Low-Btu gas, conventional } \\
\text { combustion, FBC, coal liquids } \\
\text { (e.g., SRC) }\end{array}$ \\
\hline
\end{tabular}

A mix of residential and commercial space and water heating is used to represent the utilization by the end user of the electricity or the synthetic fuels produced from coal conversion. Twenty-five 
percent of electricity space heating is assumed to utilize heat pumps. This mix of heating is selected to represent end use because it is indicative of all three forms of energy (electricity, oil, and gas) and is also representative of a significant portion of energy demand. Evaluation of so many technologies throughout entire energy systems is a very complex process. To make it more comprehensible, the evaluation is divided into three basic steps, which are summarized in tabular form in the report:

- Potential adverse impacts are calculated for unit energy systems producing equivalent quantities of useful energy. Energy efficiencies of the various processes; energy inputs and outputs; requirements of coal, ancillary energy, water, land, and manpower; and the major emissions, effluents, and solid wastes produced by the coal technologies are all considered.

- Indices that indicate the relative sizes of the major potential health, safety, environmental, and socioeconomic impacts are developed. For example, $\mathrm{SO}_{2}$ emissions are used as an index of respiratory health impacts to the general public, environmental damages to plant and animal species, and materials and agricultural production.

- $\because$ The indices of impacts are converted to potential impacts whenever existing knowledge allows it.

The sizes of the various coal systems evaluated in this report are chosen so each produces an equivalent quantity of useful energy. Thus, the system factors, indices of potential impacts, and estimated impacts are quantified for equal amounts of useful energy. They represent the potential benefits from the energy systems. 
CONCLUSIONS

Occupational Health

The conclusions relating to occupational health are as follows:

- The dominant potential occupational health impacts from the various coal energy systems are respiratory deaths and $i l i n e s s e s$ and accidental deaths and injuries. (See Chapter IV.)

- The smallest occupational health impacts are associated with the coal liquefaction and gasification to direct combustion fuel cycles. (See Chapter IV, Table 3.)

- The largest occupational health impacts are from the coal liquefaction and gasification to electricity generation fuel cycles. (See Chapter IV, Table 3.)

- Larger occupational health impacts will result from all electric fuel cycles than from all direct combustion alternatives. (See Chapter IV, Table 3.)

Public Health

The conclusions relating to public health are as follows:

- The smallest respiratôry impacts are associated with coal conversion-combustion systems. Respiratory impacts from airborne particulates expected from coal electricity generation systems are 3 to 4 times higher than from coal conversion systems. (See Chapter IV, Table 3.)

- Greater concentration of coal conversion plants in the West will further reduce the potential general public health impacts from both combustion products and from transportation relative to coal-electricity systems. The effect is due to smaller population density, smaller backgrounds of pollutants, and shorter transportation distances for western plants. (See Chapter IV.) 
Other Comparisons

Other conclusions of this report include the following:

- Coal conversion-combustion systems involve only small variations among themselves in regard to health, safety, and environmental impacts. FGD and AFBC coal-electric systems also exhibit similar impacts. (See Chapter III, Tables 2 and 3.)

- Health, safety, and environmental impacts associated with the coal electricity systems are greater than those produced by an equivalent oil system, even if flue gas desulfurization or atmospheric flyidized bed systems are employed for electricity generation. (See Chapter III, Tables 2 and 3.)

- The coal liquid conversion systems used for direct heating have greater overall energy efficiencies than systems for direct generation of electricity from coal, and therefore will require smaller quantities of coal to be mined and transported. (See Chapter II.)

- The transportation distances of coal from the mines to the energy conversion facilities will be shorter because of projected locations of the facilities relative to the mines. There is also better flex-. ibility available for siting the plants near coal mines because gaseous and liquid fuels can be shipped economically up to thousands of miles, while electricity needs to be generated not farther than a few hundred miles from customers. (See Chapter IV:)

- Emissions of combustion products will be less because only about 10 percent of the coal undergoes combustion and the fuels produced are cleaned (of sulfur) prior to utilization. Consequently, there is less pollution generated during subsequent combustion. (See Chapter V.)

- Coal conversion-combustion systems produce smaller quantities of adverse emissions than equivalent coal-electric systems. However, the emissions from utilization of the synthetic fuels are produced in close proximity to the user. They may, therefore, result in greater exposures and impacts from the same quantity of emissions as from coal-electric plants. (See Chapter V.) 


\section{INTRODUCTION}

BACKGROUND

An analysis of U.S. and world energy supplies reveals that an imbalance exists between present patterns of energy resources and energy consumption. Proven U.S. reserves and undiscovered resources of coal are estimated at $3 \times 10^{12}$ tons or about 75,000 quads* of energy (derived from National Academy of Sciences (NAS), 1975). The corresponding figures for conventional resources of crude oil are $150 \times 10^{9}$ barrels or 840 quads of energy and $780 \times 10^{12}$ cubic feet or 780 quads of energy for natural gas (derived from NAS, 1975). This means that the energy contained in the coal resources of the United States is about 50 times greater than the combined energy in crude $0 i 1$ and natural gas resources. Yet in 1974, coal accounted for only 18 percent of the gross energy use of the United States while oil and gas together supplied about 76 percent (U.S. Congress, 1977). The world situation is very similar. Although the energy content of the total world coal resources exceeds that of oil and gas by a factor of $16(275,000$ quads versus 16,700, derived from NAS, 1975), in 1974 coal supplied only 32 percent of the total world energy versus 66 percent which was derived from oil and gas (not counting wood) (United Nations, 1977).

In the United States, a shift toward direct use of coal is already taking place because of economic considerations and governmental policies. Technologies of coal conversion, i.e., converting coal to liquid and gaseous fuels, are being developed because of the need for more versatile fuels that are cleaner and easier to handle, transport, and

* Quad is a unit of energy equivalent to $10^{15}$ (quadrillion) Btu. It is approximately equivalent to $180 \mathrm{million}$ barrels of oil or to 40 million tons of bituminous coal. On the average, 1 quad is enough to supply all the present energy requirements of about 3 million Americans for 1 year. 
use than coal. Government incentives or assistance are expected to play a major role in the timing and rate of commercialization of these technologies because the projected costs of synthetic oil and gas are higher than the present import prices of these fuels.

\section{OBJECTIVES}

The main objective of this report is to review the key health, safety, and environmental impacts associated with the production of liquid fuels from coal. The information would enable government and industry policy planners, to understand and assess some of the major external costs expected: from a shift from crude oil to liquid fuels from coal. The information would enable government and industry policy planners to understand and assess some of the major external costs expected from a shift from crude oil to liquid fuels from coal.

Another objective of the study is to compare the resource requirements and health, safety, and environmental implications of the following coal energy technologies:

- Coal liquefaction -- solvent refined coal (SRC II) process

- Atmospheric fluidized bed combustion (AFBC)

- Low-Btu gasification.-- Lurgi process

- Medium-Btu gasification -- Lurgi process

- High-Btu gasification -- Lurgi process

- Conventional combustion with flue gas desulfurization (FGD)

\section{BASIS FOR SELECTION}

The other coal energy processes compared in this report have been selected on the basis of possessing as many of the following qualities as possible: being representative of available alternatives, producing versatile fuels, promising commercial success by the end of the century, and providing sufficient preliminary information for the assessment of the process and its impacts. 
In addition to synthetic liquids and gases produced from coal, we consider impacts of conventional coal combustion and use of fluid beds $(F B C)$. It is estimated that the $F B C$ process will be slightly more efficient than $F G D$ with respect to requirements fort coal. In view of the large quantities of coal consumed by utilities for electricity generation, even a slight increase in efficiency leads to a significant savings of coal resources and a reduction of potential impacts from mining, transportation, and end use.

Other benefits of FBC include lower emissions of $\mathrm{NO}_{x}$ and perhaps of some trace elements because of reduced temperature during combustion. Solid wastes are expected to be easier to handle and dispose of than sludges obtained from $F G D$ systems which requiredchemical stabilization. Issues remain with respect to control of particulate emissions (< $3 \mu m)$ and regeneration of the bed material. The greatest disadvantages of the process, however, are the economic and technological uncertainties associated with development to meet air quality standards at acceptable costs.

Several coal liquefaction processes are candidates for commercialization: direct processes including direct hydrogenation, solvent extraction, and pyrolysis, and the indirect liquefaction process. Although there is experience with indirect liquefaction, i.e., a large commercial plant using this process is in 'operation in Sasol, South Africa, iittle documented health and safety information is available. Because of this, and because direct coal liquefaction results in higher conversion efficiency and lower costs than indirect conversion, a direct process has been chosen in this report as representative of coal liquefaction processes. The SRC-II process is selected because of its nearness to commercialization; its versatility in using different coals to produce the entire range of liquid fuels from heavy boiler fuels to gasoline and chemical feed stocks; and the availability of limited information relating to health and environmental impacts.

Lurgi high-, medium-, and low-Btu coal gasification technologies offer alternatives for converting coal to energy for different types of consumers. High-Btu gas can replace natural gas for present users without the need for retrofitting. Medium-Btu gas can replace natural gas for large energy-intensive industrial and residential customers within a radius of about 100 miles of the plant. Low-Btu gas is mainiy suitable for generating electricity and process heat for large energy- 
intensive customers within short distances. The Lurgi process has been chosen because of the extensive past and present experience with low-and medium-Btu gasification plants (abroad) and the availability of information for the assessment of impacts.

METHODOL OGY

The potential health, safety, and environmental impacts of various coal technologies are evaluated within the framework of complete energy systems. All phases of the systems are considered, from exploration for coal to the end uses of the energy or fuels derived from coal. The end user is the final residential or industrial consumer who makes use of the electricity or fuels from coal supplied to him.

To provide a consistent basis for comparing impacts of various coal energy systems, the evaluations are performed for systems characterized by normalized model unit plants. The model unit plant is assumed to produce $63 \times 10^{12}$ Btu/year of useful energy at the point of end use.* Adverse impacts of resource requirements associated with similar benefits of equal amounts of useful energy can thus be compared. A mix of residential and commercial space and water heating is selected to represent end use. All three forms of energy, i.e., electricity, oil, and gas, participate in this end use. In the case of electricity, 25 percent of electricity space heating is assumed to utilize heat pumps.

To make an evaluation of the various energy systems more comprehensible, the evaluating process is divided into three basic steps:

- A concise review of the major system factors related to potential adverse impacts is performed for unit energy systems. The factors include the energy efficiencies of the various processes; energy inputs and outputs; requirements of coal, ancillary energy, water, land, and manpower; and the major emissions, effluents, and solid wastes produced by the coal technologies.

*This is the standard reference to the 250 MCFD plant. 
- Indices indicating the relative sizes of the major potential health, safety, environmental, and socioeconomic impacts are developed:

- The indices of impacts are converted to potential impacts whenever existing knowledge allows it.

HOW GOOD ARE THE DATA?

The information relating to health impacts is very uneven. Data about some effects are considerably more reliable than about others, and these data should receive more weight in making comparisons among the various technologies.

The most reliable information is that about accidental deaths from mining coal because federal regulations require their reporting. A straightforward causal relationship exists between the mining activities and the associated deaths. Sufficiently large mortality rates ensure meaningful statistical treatment and interpretation of the data. Sti11, potential errors are involved when the data are projected to future situations. As indicated in the report, a range of values differing by 100 percent is obtained by assuming that future mixes of coal will consist of 90 percent surface-mined coal rather than only 55 percent as common at present (see Chapter IV).

Representing highly uncertain data are potential respiratory health impacts to the general public from exposure to air emissions. Ranges from 0 to relatively large numbers are obtained. They indicate unceirtainties and the involvement of a large judgemental component in the estimates. Serious deficiencies of knowledge exist in practically every step of the process of evaluation of health impacts. We lack information about characterization of adverse emissions from the facilities, and environmental behavior and transport of the emissions, the resulting human exposure, derived intakes of pollutants, dose-response relationships for the pollutants, and corrections arising from exposures to combinations of stresses. It is not even clear what is the final active agent or agents that cause the adverse impacts of air pollutants, and only association rather than cause and effect relations have been determined for the various emissions and impacts attributed to them.

The reliability of the other health impacts evaluated in this report lies inbetween these two extremes. It should be apparent to the reader that different impact numbers, such as the number of deaths from coal mining and the amount of combustion emissions, cannot be simply added. The different reliabilities of the estimates require a weighting process before their addition to produce total impacts from energy systems. 
In the case of most environmental impacts, the data base is even more uncertain than for health impacts. Quantification is possible only for a limited number of cases, such as estimates of property or agricultural damage from air emissions. For most effects, it is impossible even to arrive at a broadly accepted common denominator to which the impacts can be reduced. Evaluation often depends largely on subjective human values.

MAJOR OCCUPATIONAL HEALTH AND SAFETY IMPACTS

The two dominant potential health impacts are deaths and illnesses from black lung disease associated mainly with underground coal mining and deaths and nonfatal injuries from coal mining. Black lung disease includes several respiratory diseases associated with coal mining such as chronic bronchitis, coal workers pneumoconiosis (CWP), and various obstructive respiratory airway diseases. Although chronic bronchitis or respiratory obstructive airway diseases are almost three times more common than CWP, the latter is selected as the reference index for the impact because CWP is a diagnosable disorder of the respiratory system and is clearly attributable to prolonged inhalation of coal dust. The other respiratory diseases, on the other hand, are indistinguishable from dysfunctions of the lung caused by smoking or from living in a heavily polluted area. The data base is also deficient, because reported cases of the respiratory diseases are not mutually exclusive.

Projected deaths and cases of CWP are expected to decline in the future because of a continuing shift to surface mining and because of expected implementation of the Federal Coal Mine Health and Safety Acts of 1969 and 1977, which require better control of respirable mine dust which causes CWP. However, the disease has a long delay time from exposure to diagnosis, averaging 14 years, and 10 more years before death. As a result, for a long time to come, CWP cases produced by past exposures will continue, even if the number of new cases will be reduced. 
Underground coal mining results in more deaths and injuries per ton of coal mined than surface mining (see page 41). Overall accidental rates of mining have been declining steadily during the last 50 years. Future rates depend mainly on assumptions concerning the mix of surface to underground coal in future supplies. Other factors such as regional shifts to new sources of coal, improved mine safety, changes in mining practices, and scale of operations are also important. Based on present knowledge, other less important potential health impacts, according to their importance, are as follows:

- Accidental deaths and injuries from the transportation of coal,

- Accidental deaths and injuries from construction of energy facilities, and

- Disease deaths from coal conversion.

Estimates of increased carcinogenic risks to occupational workers of coal conversion facilities have been attempted because of the great concern with the disease. The concern is $s_{15}$ based primarily on epidemiological studies indicating an increased incidence of cancers among workers routinely exposed to products of coal. Laboratory findings also indicate the potential carcinogenicity to animals and malignant transformation of bacteria and human cells of many coal products.

Preliminary estimates of the upper range values of increased carcinogenic risks from coal conversion plants have been evaluated. The derived risks for coal conversion plants are found, to be small in comparison to the other major occupational risks discussed in this section.

These preliminary estimates need verification. However, it is unlikely that either verification or much better estimates will be made in the near future, before the operation of commercial coal conversion piants. 
HEALTH AND SAFETY IMPACTS ON THE GENERAL PUBLIC

Two major categories of potential health and safety impacts are involved:

- Delayed deaths and aggravation of respiratory diseases, mainly from inhalation of combustion and transformation products, and

- Accidental deaths and injuries from the transporation of coal.

The transportation of coal by freight trains accounts for about two-thirds of all present coal transportation and is expected to retain its dominance in the future. As an approximation of the potential deaths and injuries from coal transportation, those attributed only to the portion of coal that is carried by railroads are considered.

The data available on accidental deaths and injuries from rail transport of coal are aggregated with those for all other goods carried by railroads. Coal's share of the impacts is apportioned from the data on the basis of miles traveled by coal-carrying trains. The present average haul distance is estimated at 300 miles, increasing to 450 miles by the year 2000. A mix of 60 percent mixed trains carrying 1,000 tons of coal and 40 percent unit trains carrying 10,000 tons are assumed.

Solid waste from conversion plants may contain trace elements that could contaminate water and food sources. These wastes are expected to include the bulk of the trace elements. Evaluation of the potential exposures from these sources do not exist and are needed. 
ENVIRONMENTAL IMPACTS ON PLANTS, ANIMALS, ? ECOSYSTEMS, AND PROPERTY

Environmental impacts are discussed according to their global, regional, or local nature. The most significant potential regional impacts are those from transformation products from the combustion of fossil fuels, thermal pollution from energy parks, and dry and wet depositions of gaseous and particulate pollutants. These pollutants are sulfur oxides and sulfates, particulate matter, photochemical oxidants, nitrogen dioxide, and nitrates; $\mathrm{SO}_{2}$ is used as an index of the potential impact of all these pollutants.

Acidic mine drainage from eastern coal mines and increased salinity of surface and ground waters in the vicinity of western coal fields are the significant ecological local impacts from coal mining. This acidic or alkaline mine drainage can alter both the size and species composition of aquatic ecosystems. Drainage control involves sealing the mine, which needs to be maintained every few years, and/ or neutralization of the discharges. The control is very difficult, particularly in the case of acid drainage from abandoned underground mines. Enforcement of recent mining regulations concerning the elimination of acid discharges should result in essentially no further discharges of acid to streams from active surface and underaround mines.

SOCIOECONOMIC IMPACTS

Although socioeconomic issues are not detailed in this report, they are mentioned briefly here for reference. The main socioeconomic factors affected by the energy activities are the quality of community life, employment, housing needs, service infrastructure needs, local taxes, revenues, inflation, and standard of living. These secondary effects of the energy activities, particularly if satellite services and industries attracted to the area because of growth opportunities are included, may be more significant than those from the primary consequences of the energy activities. 
The evaluation of the effects is very difficult because of their complex nature such as non equitable distribution of the costs and benefits, the need for future projections of community growth and needs, influence of other competing factors, and value judgements necessary for interpretation of the information.

The socioeconomic impacts tend to become more severe if the development takes place in small towns. They usually do not have large service vice infrastructures to accommodate the newcomers nor the means to effect rapid changes. Further difficulties are expected in areas characterized by scarce resources, such as arid regions short of water. Many of the difficulties of energy development may be mitigated by early cooperation between those planning the energy activities and the involved communities. 


\section{OVERVIEW OF COAL ENERGY TECHNOLOGIES}

COAL SYSTEMS

The various coal technologies involve different processes, products, or end uses, which may result in different health and environmental impacts. However, the systems do share some common elements and impacts and all involve the following sequence of activities: coal exploration, extraction, beneficiation, transportation, energy conversion, distribution and utilization. Waste disposal and facility decomissioning also accompany several of the above activities. Figure 1 is a summary of coal system activities and quantities in 1976.

DIRECT COMBUSTION OF COAL

Direct combustion of coal in power plant boilers has been the major method of converting coal to energy. The carbon and hydrogen in the coal are oxidized, thus converting the chemical energy of the coal into thermal energy. The heat in the products of combustion is converted into steam that can either be used directly (in a gas turbine or for heating purposes) or indirectly (to do external work or to generate electricity in a boiler.

The restrictive requirements of the Clean Air Act Amendments of 1977 make it mandatory to reduce sulfur oxide emissions from new utility and industrial boilers irrespective of the composition of the coal. Both $F G D$ and $A F B C$ offer solutions to this problem.

In FGD, a wet lime and limestone scrubbing system is employed. Limestone is a sedimentary rock that is more than 95 percent calcium carbonate and is a chemically active sulfur-capturing agent. As such, the limestone absorbs most of the sulfur oxides released during combustion. A large quantity of sludge is produced from these interactions and the waste has to be disposed of in an environmentally acceptable fashion. 


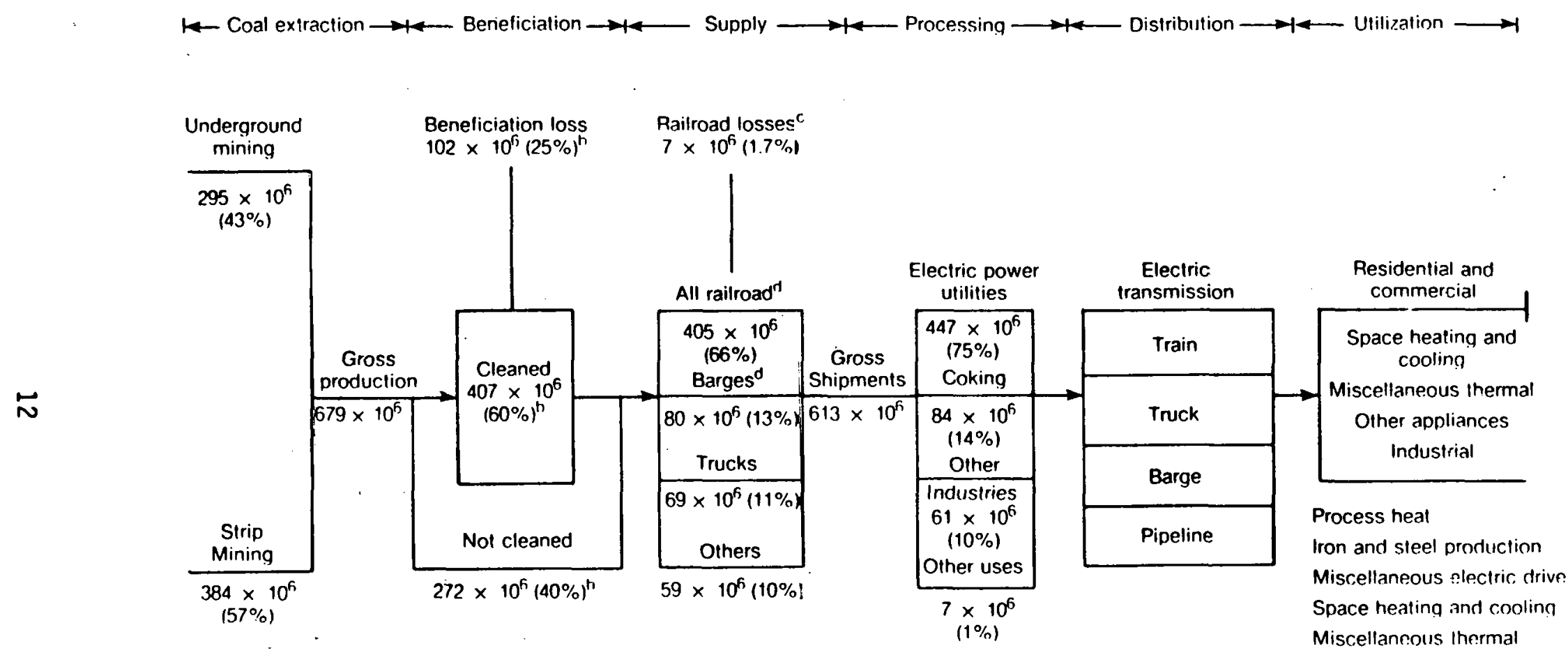

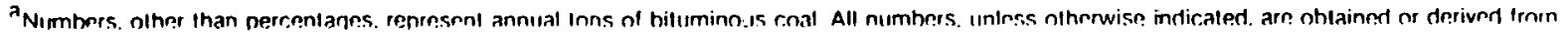
Coal Fracts. 1978-1979 iNatimnal Cogal Assorratirn 19781 and anply Ir 1976

hDorived Irmm FRDA 1974

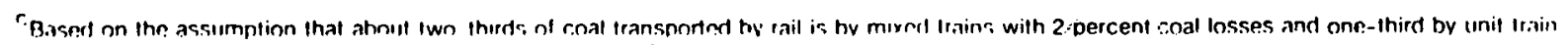

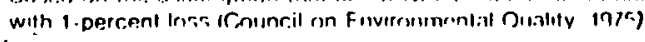

$\therefore$ "Donivert Irom Mitro. 1977

Figure 1. Summary of Coal Systems ${ }^{\mathrm{a}}$ 
FGD systems reduce the overall coal power plant efficiency by about 2 percent, from 37 to 35 percent (CEQ , 1975), but the process is still considered (by EPA) the best commercial application to reduce $\mathrm{SO}_{2}$ emissions.

In $A F B C$, the coal is burned in direct contact with limestone. Sulfur removal efficiencies are estimated to be about equal or somewhat 'lower than for FGD. However, the system is expected to be somewhat more efficient with respect to energy conversion than FGD (36.8 percent efficiency of generating electricity versus 35 percent (Brookhaven National Laboratory (BNL), 1978)). NO emissions are reduced because of lower operating temperatures and the solid wastes produced by AFBC are easier to manage than those from FGD. However, there is a large uncertainty about the reliability and costs of AFBC systems, which are still in the development stage.

COAL CONVERSION

A promising alternative to coal combustion with $F G D$ or AFBC is coal conversion to synthetic fuels which includes both coal gasification and liquefaction. The process treats coal in a reducing atmosphere and thus increases the ratio of hydrogen to carbon found in the original coal $(1 / 24$ to $1 / 14)$. When the weight ratio becomes $1 / 10$ to $1 / 6$, liquid fuels are formed (coal liquefaction); as the ratio reaches $1 / 4$, gaseous fuels are produced (coal gasification).

COAL GASIFICATION

There are many promising gasification processes, usually classified as fixed, fluidized, or entrained bed processes, depending mainly on the ways by which the feedstock, steam, and product gases are contacted and the wastes removed. A schematic diagram of the basic gasification process is given in Figure 2 (Oak Ridge National Laboratory (ORNL), 1977). 


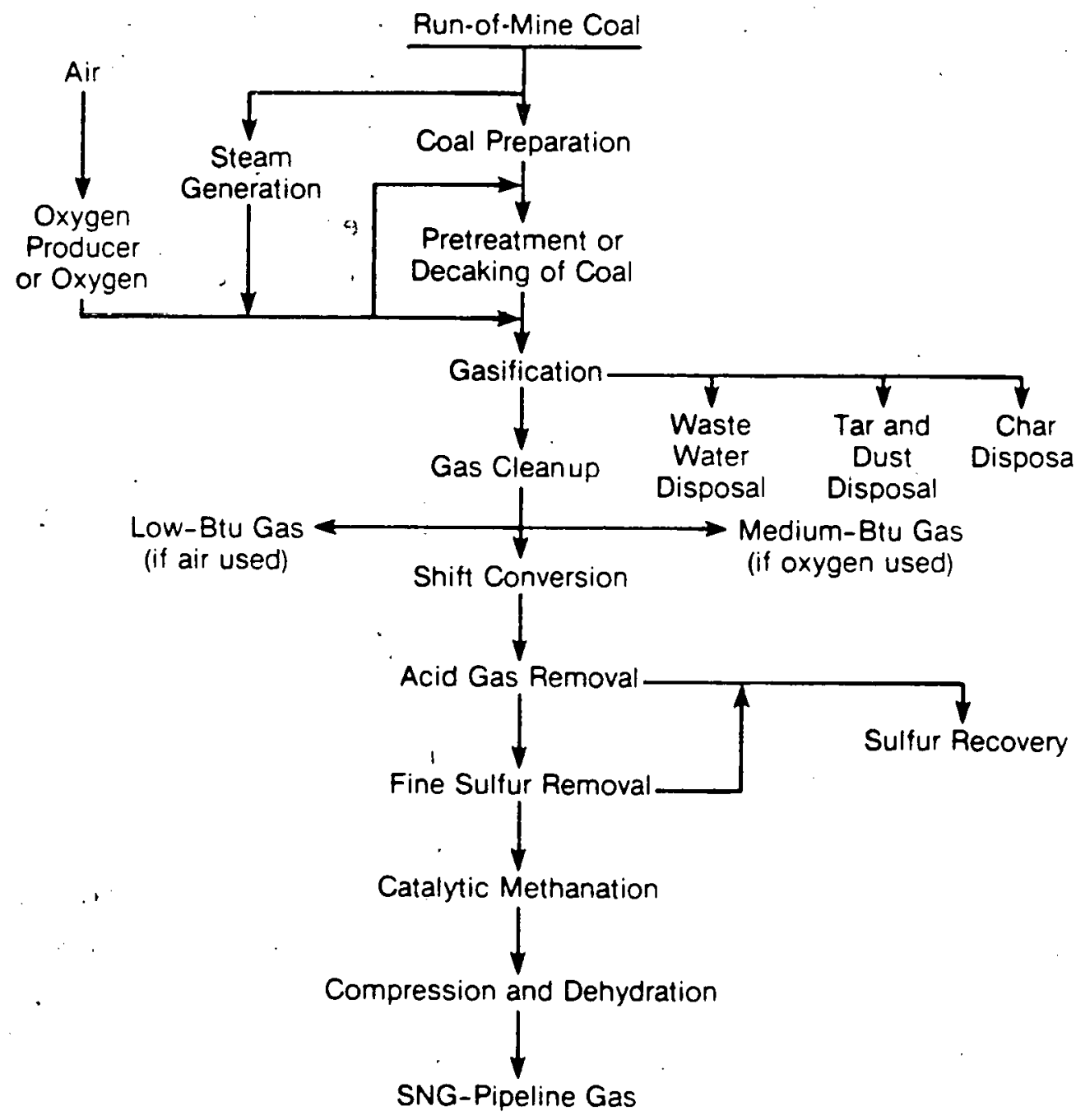

Figure 2. Schematic Diagram of Coal Gasification 
Three types of coal gas can be produced by coal gasification: low-, medium-, and high-Btu gas. Low-Btu gas has a heating value of 100 to 200 Btu per cubic foot (DOE-EPA, 1977) and is produced by reacting coal with steam and air. Medium-Btu gas is produced in the same $k$ ind of plant as low-Btu gas except that oxygen is substituted for air. As a result, the nitrogen content of the gas is lower and the heating value significantly higher than in low-Btu gas (300 to 650 Btu per cubic foot (DOE-EPA, 1977)). High-Btu gas (950 to 1000 Btu per cubic foot (DOE-EPA, 1977)), is made-from medium-Btu gases by methanation reaction and is equivalent to natural gas. The overall thermal efficiency for producing low-Btu gas from coal is between 70 and $80^{\prime}$ percent; that for medium-Btu gas is between 65 and 70 percent (NAS, 1978b); and for high-Btu gas, between 54 and 68 percent (CEQ, 1975).

The main advantages of $10 w$ - and intermediate-Btu gasification processes are their lower initial fixed cost's, lower costs of the product gases with respect to their heating values, and the greater simplicity of the process in comparison to high-Btu gasification. Purification of the product gas is relatively simple and is necessary only to the extent dictated by the user. For the case of high-Btu gas, purification of the product gas is necessary to enhance the life of the methanation catalyst. The main advantage of high-Btu product gas is that, because of its high heating value and cleanliness, it can replace natural gas. It thus becomes possible to utilize facilities which are already in place to distribute and use natural gas. High-Btu gas can be economically transported for very long distances (several thousands of miles), making it possible to be selective about the gasification plant site, so environmental impacts that are potentially deleterious may be minimized by appropriate site selection.

The most common uses envisaged for low- and medium-Btu gases are as fuels for industrial or utility boilers, for electricity generation using combined cycles, or as a feedstock to the chemical industry. Medium-Btu gas may be economically transported to consumers over short 
distances (up to 100 miles (NAS, 1978b)), or the electricity produced from the gas may be transmitted to consumers up to hundreds of miles away. However, the concept of an industrial energy park that enables the use of gas or electricity at the site of production is receiving increased attention because of economic and environmental considerations. The park is an industrial complex where the gasification facility attracts certain industries that are heavily dependent on a low-cost and uninterrupted supply of fuel (e.g., steel mill or cement factory).

\section{COAL LIQUEFACTION}

Coal liquefaction refers to processes for converting coals to synthetic hydro-carbon liquids. The liquids can be upgraded to produce high-grade gasoline blending stocks and chemical feedstocks. There are dozens of methods proposed for liquefying coal, falling into two basic processes (NAS, 1978a): indirect hydrogenation and direct hydrogenation, which includes pyrolysis, solvent extraction, and catalytic. liquefaction processes.

In indirect hydrogenation, the coal is first gasified to produce a synthesis gas composed of hydrogen and carbon monoxide. This gas is then passed over a catalyst, to produce methanol or paraffinic hydrocarbons. Methanation plants from coal have been in use in the United States since the early 1950s: A large commercial plant producting paraffinic hydrocarbons by the Fischer-Tropsch process is in operation in Sasol, South Africa. Thermal efficiencies of these plants are 45 to 60 percent (DOE, 1978). A schematic diagram of the basic indirect hydrogenation process is given in Figure 3 (DOE, 1978).

In direct hydrogenation, the coal is reacted in a hydrogen atmosphere in the presence of a catalyst under high temperature and pressure $\left(900^{\circ} \mathrm{F}, 1,500\right.$ to $\left.10,000 \mathrm{psi}\right)$. A large number of catalysts and reactor vessel configurations are being tried to obtain better thermal efficiencies, which range between 65 and 70 percent. Figure 4 (DOE, 1978) is a schematic diagram of the direct hydrogenation process. 


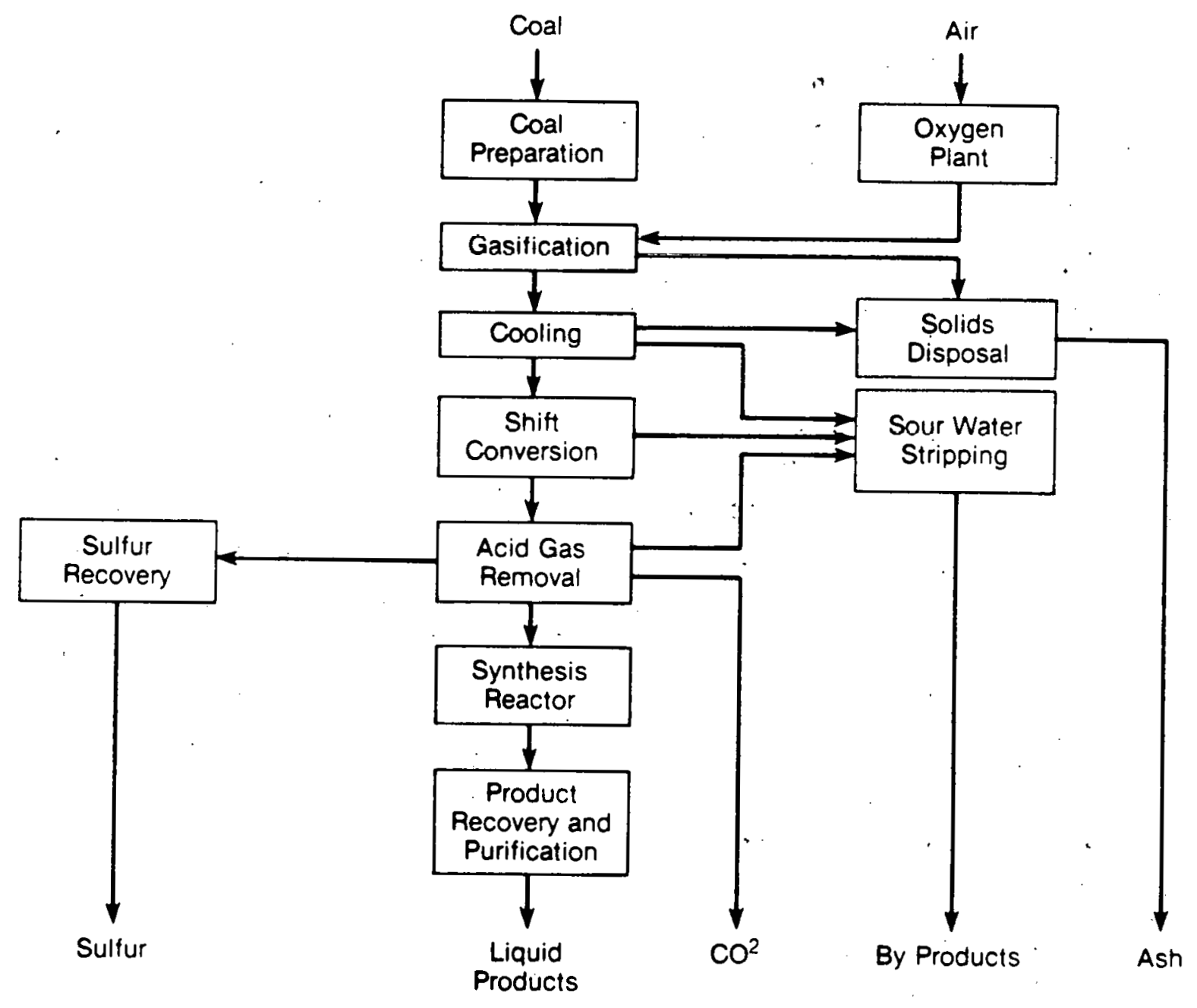

Figure 3. Generalized Indirect Liquefaction Flow Diagram 


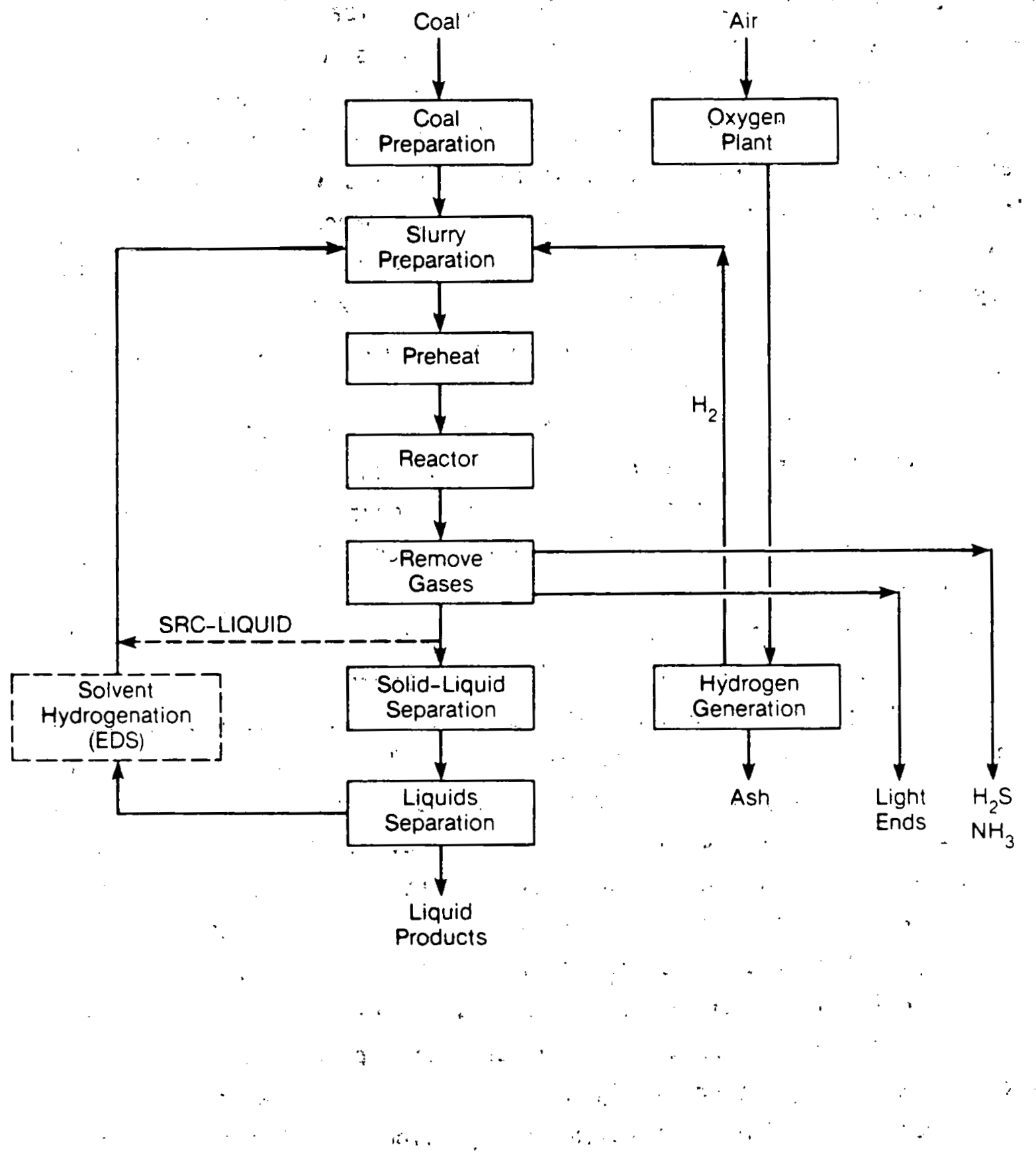

Figure 4. Generalized Direct Liquefaction Flow Diagram :- 
At present, none of the coal liquefaction processes is sufficiently well advanced for large-scale commercialization. The indirect coal liquefaction processes have the advantages of being closest to comercialization and of producing light liquids suitable for transportation fuels. They have, however, lower thermal efficiencies and greater costs than direct hydrogenation processes which have been developed through the pilot plant stage. Both processes are ready for large-scale demonstration plants. The liquid fuels will at first compete mainly for the boiler fuel market; in the future, economic processes are expected to be developed that will upgrade the products to petroleum-like finished products.

The SRC-II process is selected in this report as the representative coal liquefaction process because of its nearness to commercialization; its versatility in using different coals to.produce the entire range of liquid fuels; and the availability of information relating to health and environmental impacts.

Liquid products from the SRC-II coal liquefaction processes may be upgraded and used as boiler fuel in power-generating and industrial boilers, heating oil for homes, gasoline, or petroleum feedstocks. There are indications from limited bioassays of coal liquefaction streams that they may include higher concentrations of carcinogenic and toxic. substances than natural petroleum products. The evidence, which is largely speculative with little hard data to substantiate it because of the preliminary state of the technology, calls for a prudent approach of evaluating the potential health hazards in relation to workers and to members of the general public. The hazards may arise during the storage, distribution, and utilization of the coal liquefaction products. Exposure to toxic substances may occur mainly through skin contact with the liquefaction products or from inhalation or ingestion of effluents, fugitive

The Fischer-Tropsch process practiced in Sosal, South Africa, needs technological modifications to be suitable for American markets (DOE, 1978). 
emissions, or contaminated food. Research is needed, particularly concerning chemical and bioassay analyses of the products, evaluation of potential exposure routes, and estimates of potential carcinogenicity and dose-response relationships associated with low levels of exposure. If it is determined that significant potential health hazards exist, the data will provide a basis for an improved control and safety program, including modifications of plant design, processes, "transportation, dis-" tribution, and utilization procedures.

The estimated time until operation of direct liquefaction plants is about 10 years. The completion of EDS and $\mathrm{H}$ coal pilot plants by early 1980 is expected to reduce the uncertainty involved in this estimate. It is estimated to take at least 15 years to develop a fuel industry producing 3 to 4 million barrels of oil per day (about 6 . to 8 quads annually (NAS, 1978a)). 


\section{SYSTEM CHARACTERISTICS OF MAJOR TECHNOLOGIES}

The important factors of energy efficiency, pollutant emissions, wastes, and resource requirements appliable to coal liquefaction systems are summarized in Table 1 and compared with those of other competing coal technologies. The table attempts to quantify them in a consistent manner as a basis for evaluation of the potential health, safety, and environmental impacts. Eleven systems are compared.

Plant $A$ is a $50 \times 10^{3}$ BPD coal liquefaction plant producing 45 $x 10^{3} \mathrm{bbl}$ of oil daily, averaging $5.6 \times 10^{6} \mathrm{Btu} / \mathrm{bbl}$, and utilized direct$7 y$ by end users. Plant $B$ is a $97 \times 10^{3}$ BPD coal liquefaction plant producing $88 \times 10^{3} \mathrm{bbl}$ of oil daily, averaging $5.6 \times 10^{6} \mathrm{Btu} / \mathrm{bbl}$, and utilized for generating electricity in a 2800 -MWe power plant with FGD, which produces 2100 MWe of electricity for end users.

Plant $C$ is a 2800-MWe electric power plant with FGD, producing 2:100 MWe of electricity, and Plant $D$ is a 2800-MWe electric power plant with $A F B C$, producing 2100 MWe of electricity. Plant $E$ is an AFBC plant producing $180 \times 10^{12}$ Btu heat/year.

Plant $F$ is a $300 \times 10^{7}$ s.c.f./day low-Btu coal gasification plant producing $270 \times 10^{7}$ s.c.f. of gas daily with 100 Btu/s.c.f. gas utilized directly by end users. Plant $G$ is a $480 \times 10^{7}$ s.c.f. of low-Btu gas daily with gasification plant producing $430 \times 10^{7}$ s.c.f. of low-Btu gas daily with 100 Btu s.c.f., integrated with 2800 MWe combined cycle electric power plant with FGD producing 2100 MWe of electricity for end users.

Plant $H$ is a $930 \times 10^{6}$ s.c.f./day medium-Btu coal gasification plant producing $830 \times 10^{6}$ s.c.f. of gas daily with 300 Btu s.c.f. for direct utilization by end users. Plant $I$ is a $1590 \times 10^{6}$ s.c.f./day medium-Btu coal gasification plant producing $1430 \times 10^{6}$ s.c.f. of gas daily with 300 Btu s.c.f., integrated with 2800 MWE combined cycle electric power plant with FGD producing 2100 MWe of electricity for end users. 
Table 2. Syotem Factors Related to Potential Adverse Health, Safety, and Environmental Impacts from Unit Energy Syatems Producing Annually $63 \times 10^{12}$ Btu of Useful Energy ${ }^{a}$

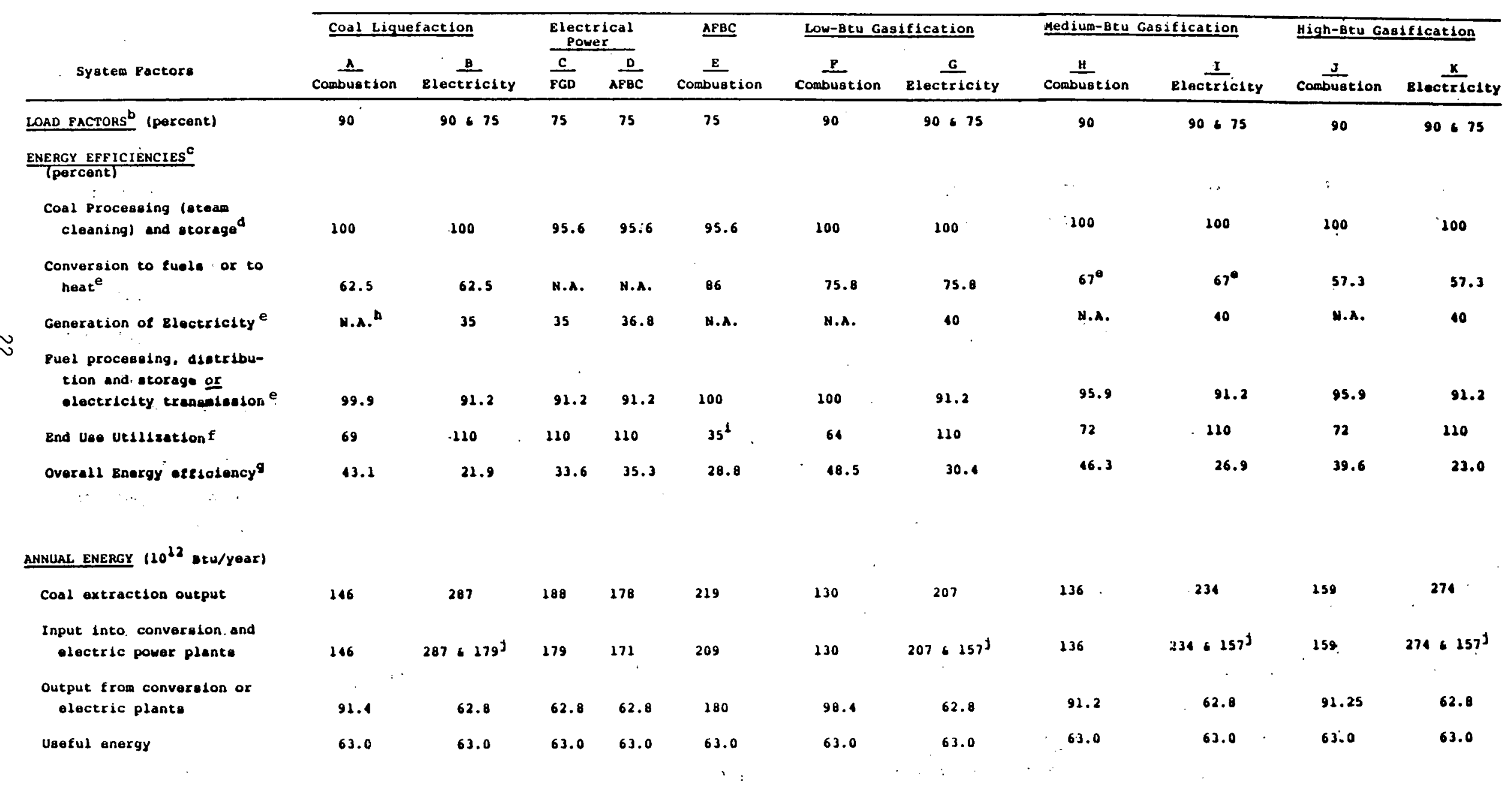


Table 1. System Factors Related to Potential Adverse Health, Safety, and Environmental Impacts from

Unit Energy Systems Producing annually $63 \times 10^{12}$ Btu of Useful Energy (Continued)

Processes Compared

\begin{tabular}{|c|c|c|c|c|c|c|c|c|c|c|c|c|}
\hline \multirow[b]{3}{*}{ System Factors } & \multirow[b]{3}{*}{. } & \multirow{2}{*}{\multicolumn{2}{|c|}{ Coal Liquefaction }} & \multirow{2}{*}{\multicolumn{2}{|c|}{$\begin{array}{l}\text { Electrical } \\
\text { Power } \\
\end{array}$}} & \multirow{3}{*}{$\frac{\underline{A F B C}}{\frac{E}{\text { Combustion }}}$} & \multirow{2}{*}{\multicolumn{2}{|c|}{ Low-Bku Gasification }} & \multirow{2}{*}{\multicolumn{2}{|c|}{ Medium-Btu Gasification }} & \multirow{2}{*}{\multicolumn{2}{|c|}{ High-Btu Gasification }} \\
\hline & & & & & & & & & & & & \\
\hline & & $\frac{A}{\text { combustion }}$. & $\frac{B}{\text { Electricity }}$ & $\overline{\frac{C}{E G D}}$ & $\frac{D}{A F B C}$ & & $\frac{P}{\text { combustion }}$ & $\frac{\mathbf{G}}{\text { Electricity }}$ & $\frac{H}{\text { Combustion }}$ & $\frac{I}{\text { Electricity }}$ & $\frac{\mathrm{J}}{\text { Combustion }}$ & $\frac{x}{\text { Electriclty }}$ \\
\hline
\end{tabular}

CONVERSION PLANT INEORMATION

ANNUAL RESOURCE REQUIREMENTS

Coal Mined ${ }^{k}\left(10^{6}\right.$ tons $)$

$$
6.64
$$

13.0

$8.55 \quad 8.09 \quad 9.95$

5.91

9.41

6.18

10.6

7.23

12.5

Coal converted or combusted $\left(10^{6}\right.$ tons $)$.

6.64

$13.0 \times 8.14^{j} \quad 8.14 \quad 7.77 \quad 9.50$

$5.91 \quad 9.4167 .14^{j}$

6.18

$10.6 \div 7.14^{5}$

$7.2312 .5 \div 7.14^{5}$

Ancillary. fuel oil $\left(10^{6}\right.$ barrels)

Land $\left(10^{3}\right.$ acres $)$.

$0.01 \quad-\quad \quad-\quad \quad-\quad-$

$\omega$

water $\left(10^{9}\right.$ gallons $)$

0.63

$\begin{array}{llll}1.7 & 4.2 & 3.9 & 0.78\end{array}$

0.22

0.48

$13^{n, 0}$

11

0.22

0.41

$-$

MANPOWER REQLIREMENTS

Peak construction (men)

\begin{tabular}{|c|c|c|c|c|}
\hline 2,200 & 3,300 & 2,400 & 2,400 & 2,900 \\
\hline 7,500 & 11,600 & 9,300 & 9,300 & 11.000 \\
\hline 1,300 & 1,500 & 410 & 400 & 490 \\
\hline
\end{tabular}

1,500
3.400
320

2,600
7,500
500

3,200
7,100

4.300

$-$

$0.6^{\mathrm{P}}$

$-$

Constructicn (man-yearo)

Operation (men)

$1,300 \quad 1,500$

ANNUAL AIR EMISSIONS $\left(10^{3}\right.$ tORB

so $_{x}$

NO $_{x}$

Particulates

HC

co

$\mathrm{CO}_{2}$

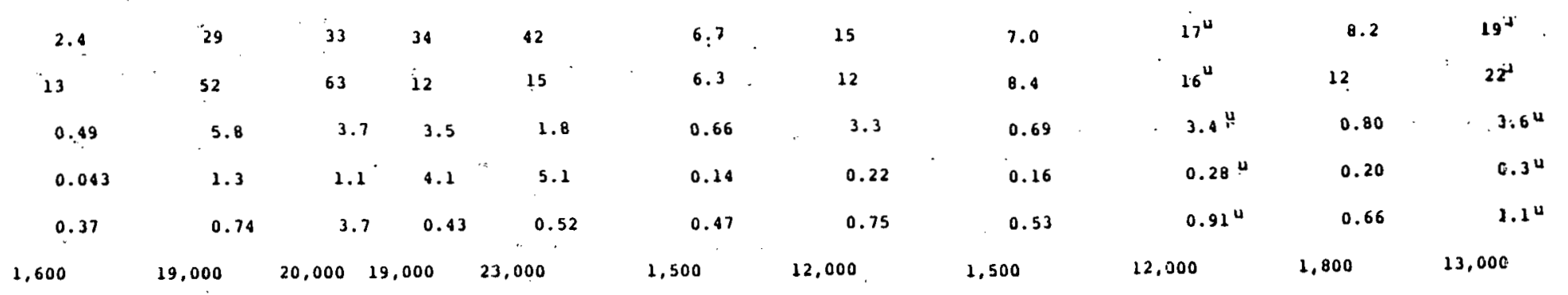


Table 1. System Pactore Rolated to Potential Adverse Health, Safety, and Environmental Impacts from

Unlt Energy Systems Producing Annually $63 \times 10^{12}$ Btu of Uaeful Energy (Continued)

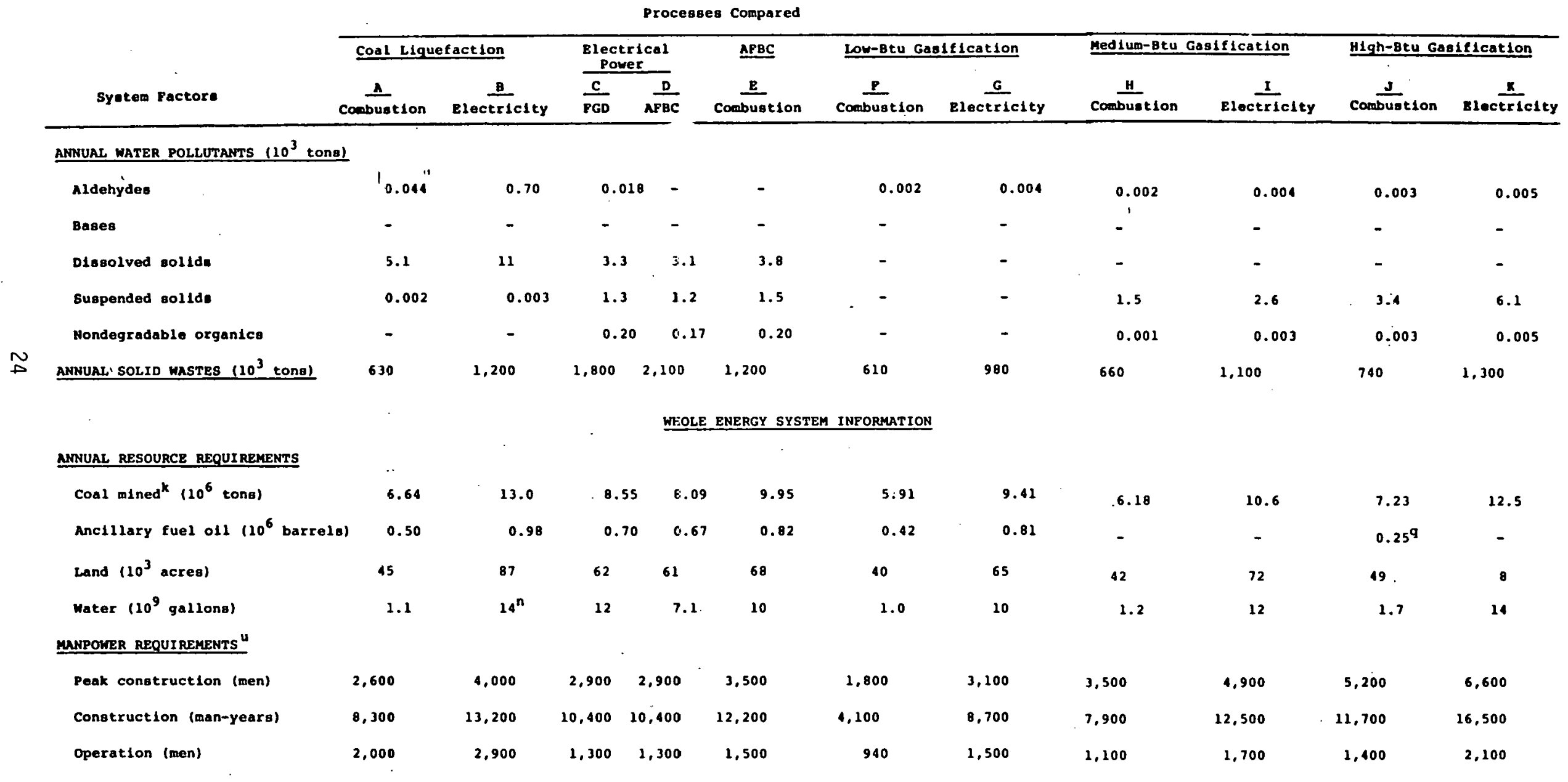


Table 1. System Factoro Related to Potentlal Adverse Health, Safety, and Environmental Impacto from

Unit Energy Systems Producing Annually $63 \times 10^{12}$ Btu of Useful Energy" (Continued)

Processea Compared

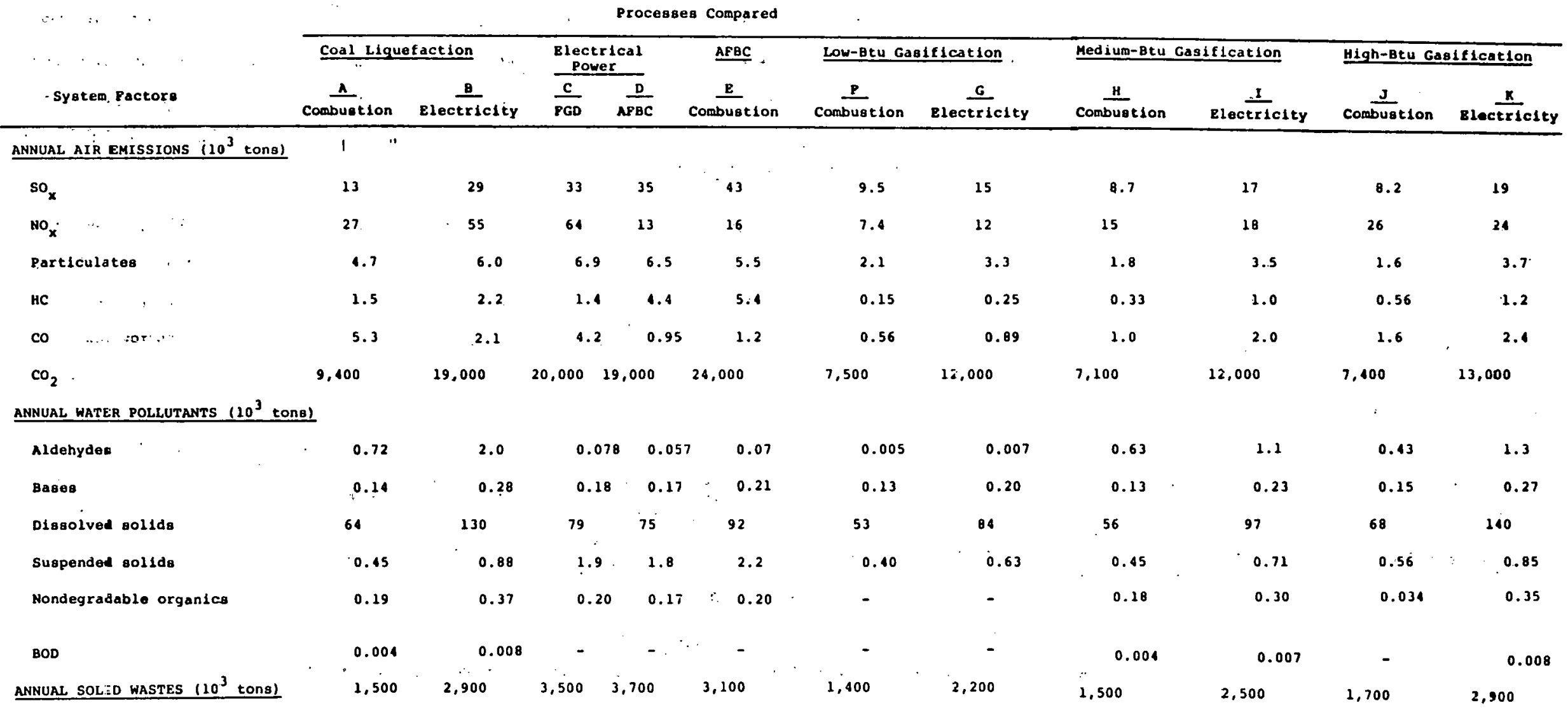


Notes to Table 1

${ }^{a}$ Coal with heating value of $22 \times 10^{6}$ Btu per ton, sulfur content of . 2 percent, and ash content of 9 percent is assumed. Controlled technologies are assumed for the various processes. Residual oil with 5.6 million Btu per barrel and 0.6 percent sulfur are also assumed.

$b$ Load factors of 90 percent for conversion plants and 75 percent for electric generating plants are derived from CEQ (1975).

C The efficiencies are based on estimates by BNL (1978). No transportation or distribution losses of coal, $0 i 1$, or gas are as.sumed because the estimates are based on controlled technologies (except 0.1 percent oil product loss for the 50 percent of oil stored in floating iroof tanks). Other sources (e.g., CEQ, 1975) assume 1-percent coal losses. for unit trains, 2-percent losses for mixed trains, and 0.7 to 0.8 percent losses for pipeline distribution of oil products (Perry, 1972). Assumed is 0.4-percent ancillary energy for distribution of oil products to homes, which are also neglected in the BNL estimates.

d Only steam cleaning losses are assumed by BNL (1978). Beneficiation losses (estimated as 5 to 45 percent by Radian (1976) and averaging about 20 percent) or even grading and sizing coal losses are not considered.

e Derived from BNL (1978).

f Utilization refers to a mix of residential and commercial space and water heating. The following efficiencies (defined as energy outputs from the appliances divided by energy inputs) are derived for the.. various forms of energy (based on CEQ, 1975): 
Notes to Table 1 (continued)

\begin{tabular}{|c|c|c|c|c|}
\hline Energy Form & Residential & Heating & Commericial & Heating \\
\hline & Space & Water & Space & Water \\
\hline Natural gas & 75 & 64 & 77 & 64 \\
\hline $0 i 1$ & 63 & 50 & 76 & 50 \\
\hline Electricity - resistance $-75 \%$ & 95) & 92 & 95) & 92 \\
\hline & $\lcm{119}$ & & ) 119 & \\
\hline Heat pump $-25 \%$ & 190) & & 190) & \\
\hline
\end{tabular}

The following mix of fuels is assumed for the year 2000 (derived from BNL, 1978):

\begin{tabular}{|c|c|c|c|c|}
\hline \multirow{3}{*}{ Energy Form } & \multicolumn{2}{|c|}{ Residential Heating } & \multicolumn{2}{|c|}{ Commercial Heating } \\
\hline & Space & Water & Space & Water \\
\hline & (\% allocation & (\% allocation) & (\% allocation) & (\% allocation) \\
\hline Natural gas & 42.0 & 21.1 & 28.5 & 8.4 \\
\hline $0 i 1$ & 41.9 & 4.5 & 53.6 & - \\
\hline Electricity & 42.0 & 25.3 & 26.0 & 6.7 \\
\hline
\end{tabular}

The following weighted efficiencies of the energy forms are obtained:

\begin{tabular}{|c|c|}
\hline Energy & Weighted \\
\hline Form & $\begin{array}{c}\text { Efficiency } \\
(\%)\end{array}$ \\
\hline Natural Gas & 72 \\
\hline $0 i 1$ & 69 \\
\hline Electricity & 110 \\
\hline
\end{tabular}


Notes to Table 1 (continued)

9 Overall energy efficiency is defined as the ratio between the number of Btu's leaving the appliances that use the fuel or electricity to the number of Btu's contained in the mined coal.

h N. A. = not applicable.

$i$ The heat from the boiler is applied as process heat for industrial applications. The average heat transfer efficiencies of individual industrial plant equipment used in direct heat operations ranges between 20 and 30 percent (CEQ, 1975). The overall efficiencies of plant systems, as distinct from individual equipment, are even lower. Assumed are increased heat conservation practices and devices that would increase the heat utilization efficiencies to 35 percent by the year 2000.

$j$ The first figure refers to energy input into the conversion plant; the second figure, into electricity generation.

${ }^{k}$ Coal mix mined by the following technologies is assumed by BNL (1978). Room and pillar underground mining, 55.0 percent; auger, 5.6 percent; strip mining with slope smaller than $15^{\circ}, 27.5$ percent. The values given are derived from BNL (1978) and are annual increments, assuming a plant life of 30 years. To obtain the life cycle land requirements, the figures need to be divided into a fixed land component for the plant, which remains constant throughout its 1 ife, and an incremental annual demand mainly for waste management and disposal, which should be multiplied by the life of the plant in years.

$m$ Includes resource requirements of coal conversion, electricity generation, or combined coal conversion and electricity generation. plant.

$n 11 \times 10^{9}$ gallons per year water requirements of the electricity plant were added to $2 \times 10^{9}$ gpy requirements for the liquefaction plant. 
Notes to Table 1 (continued)

- It is assumed that about 10 percent of the coal in conversion plants is combusted to provide energy for the conversion reactions (Perry, 1977). Factors of production of $\mathrm{CO}_{2}$ from coal, $0 \mathrm{il}$, and natural gas production are $112,000,85,000$, and 61,000 tons per $10^{12} \mathrm{Btu}$ of fuel (BNL, 1975). The $\mathrm{CO}_{2}$ production obtained from coal conversion is added to the $\mathrm{CO}_{2}$ production from electricity generation.

$P$ Extrapolated from land areas for low- and high-Btu coal gasification plus land increment for plant.

9 Also requires $5.1 \times 10^{7}$ Btu of electricity (BNL, 1978) annually.

$r$ Extrapolated proportionately to input energy from low- and high-Btu conversion plants.

$S$ Extrapolated from conversion plant requirements of medium- and high-Btu plants relative to energy input into plant plus electrical power water requirements.

$t$ Manpower requirements for electricity generation with FGD, coal liquefaction, and high-Btu gasification are derived from Carasso (1975) and Radian (1976). The figure for a coal liquefaction plant is probably on the high side, because economics of scale are not completely incorporated from a facility producing 21,700 barrels of oil per day. The following estimates are made: AFBC electrical power manpower requirements are assumed to be similar to those of an FGD plant of equal energy input. Combined coal conversion and electrical generation plants are assumed to require similar manpower requirements as the conversion plants plus half the manpower of coal electricity plant of equal size. Medium-Btu gasification plant manpower requirements are assumed to be halfway between those of high-and low-Btu gasification.

UTe main additional manpower requirements for coal systems per million tons of coal are as follows (Radian, 1976): 
Notes to Table 1 (continued)

Peak (men) Man-years

Surface mining

Underground mining

Weighed average (55\% surface)
46.0

68.0

69.3

194

125

55.9
Construction

Operation

Men

17.6

211

105

$\checkmark$ Emissions from medium-Btu gasification plants are averaged from lowand high-Btu gasification plants and corrected for differences in coal inputs.

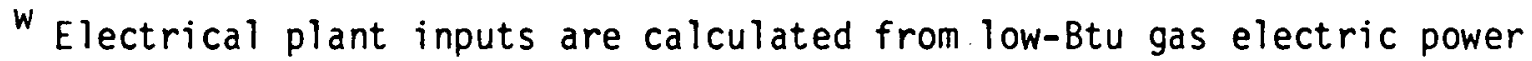
plant factors (BNL, 1978). 
Plant $J$ is a $280 \times 10^{6}$ s.c.f./day high-Btu coal gasification plant producing $250 \times 10^{6}$ s.c.f. of gas daily with $1000^{\circ}$ Btu/s.c.f. utilized directly by end users. Plant $K$ is a $480 \times 10^{6}$ s.c.f./day high-Btu coal gasification plant producing $430 \times 10^{6}$ s.c.f. of 1000 Btu/s.c.f. gas daily, integrated with 2800 MWe combined cycle electric power plant producing 2100 MWe of electricity for end users.

The sizes of the various unit systems of Table 1 were selected to deliver an equivalent unit of useful energy to the end user. The sizes of the systems are based on the quantity of useful energy expected from a high-Btu coal gasification system that produces 250 million standard cubic feet of gas daily with energy content of 1000 Btu per cubic foot, which is the size of a commercial gasification plant expected to be built in the future.

The load factor of a facility is defined as the ratio between the actual annual output of energy and the theoretical peak output if the plant is operated continuously at full capacity. Average load factors of 75 percent are selected for electrical power plants of Table 1. They are more representative of base-load plants that operate continously at or near full capacity than for intermediate and peak load units that operate for shorter periods and have lower factors.

The annual resource requirements of coal, ancillary fuel oil, land, water, and manpower are estimated for each type of energy conversion plant and for whole energy systems. A distinction is made beween the coal quantities that need to be mined and those that are combusted and converted to energy. The impacts from the early phases of the fuel cycle - mining, preparation, and transportation - are directly proportional to the former values. Impacts from conversion, distribution, and utilization are proportional to the latter values. Resource requirements, emissions, water pollutants, and solid wastes are summarized in Table 1 for both the energy facility and the energy system. Energy facility refers to the electrical generation and coal conversion, or integrated coal conversion combined cycle power plant. Energy system refers to all the phases that 
relate to the energy facility: coal exploration, mining, beneficiation, transportation, conversion, distribution, and utilization.

In the case of land, most of it is required for electrical transmission. Water is mainly consumed in power plant cooling. Manpower requirements are mainly divided between construction and operation of the energy facility ano coal mining. The distribution of manpower between these two phases is such that most of the construction manpower is associated with the energy facility. The bulk of operational manpower is made up of coal miners to extract the coal, but with significant numbers of workers required to operate and maintain the energy facility.

Combustion products including $\mathrm{CO}_{2}$ are mainly produced in the energy facility. In the case of production of liquid and gaseous fuels by coal conversion, significant emissions of combustion products are also produced during the utilization of fuels. Water effluents are mainly produced during the mining of the coal. Solid wastes are divided between coal mining and energy conversion, with coal mining producing about half to two-thirds of the wastes.

Table 2 sumarizes the indices of major potential health, safety, and environmental impacts from unit energy systems of the various coal energy systems of Plants $A$ through $K$ described previously. A conventional oil energy system ( $P$ lant $L$ ) is also included in this table for comparison with the coal systems. The following indices are employed:

- Coal consumption provides an index of the major occupational health inpacts to miners from respiratory and mining accident impacts and is also an index of general public coal transportation impacts.

- $\mathrm{SO}_{2}$ emissions provide an index of the respiratory health impacts to the general public from combustion products, of the damages to plants, animals, soils, and ecosystems from combustion products, and of the damages to property and to agricultural production.

- $\mathrm{CO}_{2}$ emissions provide an index of long-term weather modifications. 
Table 2. Indexes of Major Potential Health, Safety, and Environmental Impacts from Unit Energy Systems Producing Annually $63 \times 10^{12}$ Btu of Useful Energy

\begin{tabular}{|c|c|c|c|c|c|c|c|c|}
\hline \multirow[b]{2}{*}{ Index } & \multirow[b]{2}{*}{ Related Impact } & \multicolumn{7}{|c|}{ Power Plants Compared } \\
\hline & & $\begin{array}{c}\text { A } \\
\text { Codl Lla } \\
\text { Conbust ion }\end{array}$ & $\begin{array}{c}\quad y \\
\text { uef action } \\
\text { lect ricity }\end{array}$ & $\begin{array}{l}2 \\
\text { Electrical } \\
\text { rGD }\end{array}$ & $\begin{array}{c}\text { D } \\
\text { Power with } \\
\text { Af BC }\end{array}$ & $\begin{array}{c}\text { AFBC } \\
\text { Conbustion }\end{array}$ & $\begin{array}{c}\text { F } \\
\text { Low-Btus } \\
\text { Combustion }\end{array}$ & $\begin{array}{c}6 \\
\text { iasiffcation } \\
\text { Electricity } \\
\end{array}$ \\
\hline $\begin{array}{l}\text { Annual Quantitles } \\
\text { Mined Coal } \\
\text { (106 tons/year) }\end{array}$ & $\begin{array}{l}\text { Occupat lonal mining: } \\
\text { impact (Oup and } \\
\text { mining accidents) }\end{array}$ & $\begin{array}{c}6.6 \\
.\end{array}$ & 13 & B.6. & 8.1 & 10.0 & 5.9 & 9.4 \\
\hline$\therefore$ & $\begin{array}{l}\text { General publlac tmpact } \\
\text { from transportation }\end{array}$ & & & & & & & \\
\hline \multirow[t]{3}{*}{$\begin{array}{l}\text { Annual emisslons of } \\
\mathrm{Su}_{2}\left(10^{3} \text { tons/year }\right)\end{array}$} & $\begin{array}{l}\text { General publlc impact } \\
\text { from combust ion products }\end{array}$ & 13 & 29 & 33 & 35 & 43 & 9.5 & 15 \\
\hline & Damages to environment & & & & & & & \\
\hline & $\begin{array}{l}\text { Danages to property and } \\
\text { agr fcultural products }\end{array}$ & & & & & & & \\
\hline $\begin{array}{l}\text { Annual emisslons of } \\
\mathrm{CU}_{2}\left(10^{6} \text { tons/year }\right)\end{array}$ & $\begin{array}{l}\text { Long-term weather } \\
\text { modification }\end{array}$ & 9.4 & 19 & 20 & 19 & 24 & 7.5 & 12 \\
\hline \multirow{2}{*}{$\begin{array}{l}\text { Land use }\left(10^{3} \text { acres/ }\right. \\
\text { per year) }\end{array}$} & Damoges to land & 45 & 87 & 62 & 61 & 68 & 40 & 64 \\
\hline & $\begin{array}{l}\text { Soctoeconomic Impact } \\
\text { compet ing land uses }\end{array}$ & & & & & & & \\
\hline $\begin{array}{l}\text { Peak Construct ton } \\
\text { Manpower (men) }\end{array}$ & $\begin{array}{l}\text { Socioeconomic Impoct } \\
\text { comminity growth }\end{array}$ & 2.600 & 4,000 & 2.900 & 2,900 & 3,500 & 1.800 & 3.100 \\
\hline $\begin{array}{l}\text { Operat fonal Manpower } \\
\text { (men) }\end{array}$ & $\begin{array}{l}\text { Soctoeconomic impact } \\
\text { communtty growth }\end{array}$ & 2,000 & 2,900 & 1,300 & 1,300 & 1,500 & 940 & 1,500 \\
\hline $\begin{array}{l}\text { Natgr consumplion } \\
\text { (109 gallons/year) }\end{array}$ & $\begin{array}{l}\text { Socioeconomic impact } \\
\text { compet ing water uses }\end{array}$ & $1: 1$ & 14 & 12 & 7.1 & 10 & 1.0 & 10 \\
\hline
\end{tabular}

* These figures do not include $\mathrm{CO}_{2}$ production from. $\mathrm{H}_{2}$ generation for gasification or liquefaction processes. An additional amount of $\mathrm{CO}_{2}$ (approximately 35\% by weight) derives from these sources. 
Table 2. Indexes of Major Potential Health, Safety, and Environmental Impacts from Unit Energy Systems Producing Annually $63 \times 10^{12}$ Btu of Useful Energy (Continued)

Power Plants Compared

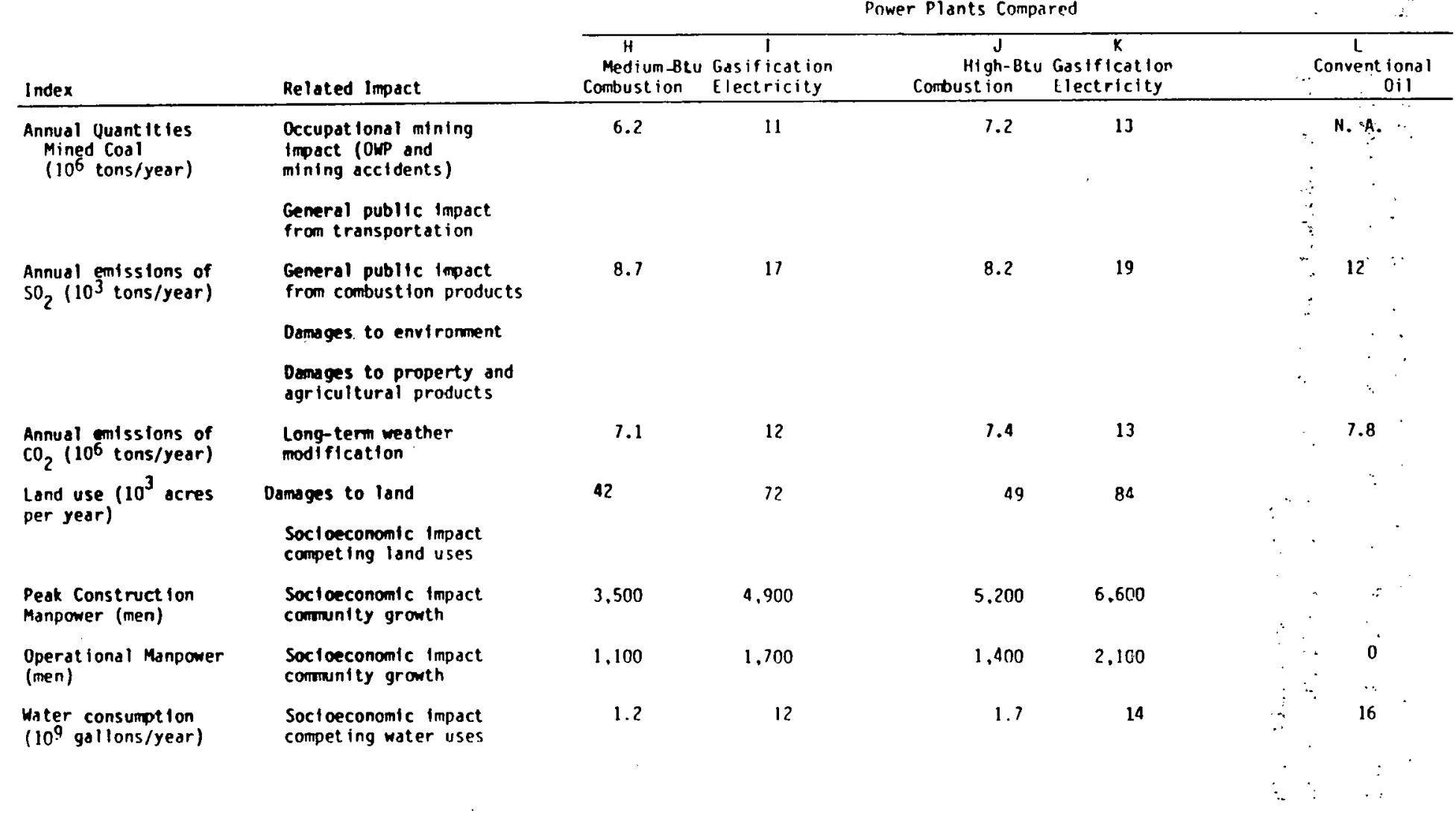


- Land use is indicative of land impacts, mainly to plant and animal species and to ecosystems, and of socioeconomic impact.

- Water consumption and manpower requirements are related to socioeconomic impacts. 
The health and safety impacts to occupational workers and members of the general public from the various coal technologies discussed in this report can be classifjed into two general groups: those common to coal electricity systems and those associated with specific coal conversion processes including the refining, distribution, and utilization of conversion products and byproducts.

The first group includes mainly impacts from the mining and transportation of coal and from exposure to combustion and transformation products. Some of these impacts have been extensively investigated and substantial resources have been allocated to obtain better data about them to improve evaluations of the associated risks. 0thers, such as the transportation impacts from coal, have received less attention.

The second group is to a large extent uncertain because the conversion processes are still under development. Substantial changes in these processes are expected before they become commercial, which will affect the nature of potential risks. It is possible to speculate about the impacts from limited data collected from pilot plants; however, there are difficult scaling problems in applying the data to comercialsized future plants. Little data exist with respect to potential impacts from refining, distribution, and utilization of synthetic oils; and only limited information about impacts can be gained about a new process or industry from extrapolations of impacts from other similar processes.

In the case of coal conversion, such similar processes are coal coking or oil refining. Useful information can also be collected from various laboratory tests that are applicable to residuals from coal conversion pilot plants. Data on the toxicity of residuals of various coal conversion processes including liquifaction have been collected. The residuals are administered to various animals, bacteria, and even human cell culture systems. Epidemiological studies of exposed workers or members of the general public cannot be undertaken at this time 
because the number of exposed individuals and the duration of exposures have been too small and short. Therefore, only discussion of the most obvious effects is possible, leaving assessment of less obvious impacts to speculation.

Many kinds of sources of health and safety impacts are associated with the various coal energy technologies. Table 3 summarizes the harmful impacts according to the phase of the energy system at which they occur and as they affect both occupational workers and the general public, it should be emphasized that the heaith effects of different energy processes and systems cannot be compared on the basis of equal numbers of projected deaths, injuries, or illnesses. Data on some impacts are considerably more reliable than others.

The most reliable data are those concerning accidental deaths and injuries from coal mining, because federal regulations require their reporting, validation, and investigation. A straightforward causal relationship exists between coal mining and associated accidental deaths and injuries, and sufficiently large numbers of fatalities and injuries are involved to allow meaningful statistical treatment of the data. Differences in the reliability of the information exist, however, between deaths and injuries, with greater uncertainties associated with the injury data. Furthermore, use of the information of both deaths and injuries involves potential errors that are mainly due, not to the data base itself, but to the need to manipulate the data to make projections for future situations. The projected rates of accidental deaths and injuries from mining depend on assumptions of future mining productivity, types and mixes of mining, accident-prevention technologies, and the extent of implementation of safety regulations.

Assessments of safety risks are generally more reliable than those of damages to health or of delayed deaths from exposures to toxic substances. The reasons are that causal relationships exist between accidents and impacts, and more abundant data are aváilable for evaluation. There are, however, serious deficiencies associated with the detail of the data and with projections from present situations. 
Table 3. Major Annual Health and Safety Impacts Prom Some Energy Systems Based on Unit Plante (cases/year)

Process compared

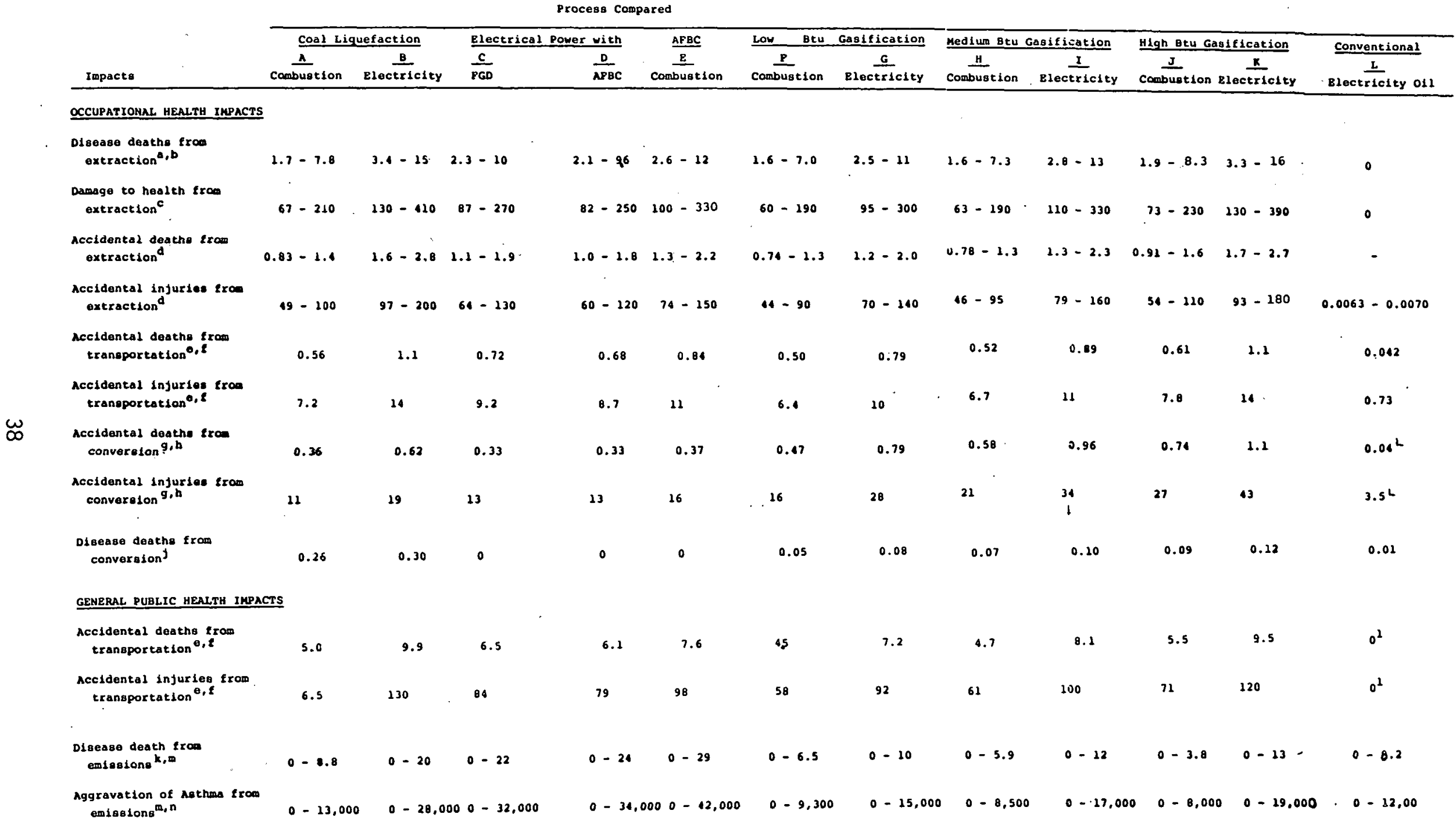


a. Two mixes of coal mining are assumed: 55 percent surface mining as during 1976, and 90 percent surface mining projected to mining in the year 2000 (Accidents and Unscheduled Events Associated with Non-Nuclear Resources and Technology, prepared by C. P. Bliss for U.S. Environmental Protection Agency, EPA/600/7-77-016, Washington, D.C.: 1977. Hereinafter cited as MITRE Corp., Accidents and Events, NIOSH 1977) and more representative of coal supplies to conversion plants which are expected to be concentrated in the Western States.

b. Based on 2.62 deaths from Coal Workers Pneumoconiosis (CWP) per million tons of coal from underground mining. The figure is derived from the incidence of CWP deaths for the years 1949-1969 (Baldewicz, W. et a11, 1974 and rates of underground coal mining during this period (National Coal Association, 1977.).

c. 65.0 new cases of CWP were reported by NIOSH for 1976 per million tons of underground mining, and 4.0 cases per million tons of surface mining (NIOSH 1977).

0.10 accidental deaths and 5.2 accidental injuries are estimated for surface mining of $10^{6}$ tons of coal. The corresponding figures for underground mining are 0.35 and 28 deaths and injuries per $10^{6}$ tons of coal. The estimates are based on extrapolation from recent rates (NAS 1976, NIOSH 1977, National Coal Association 1977, Baldewicz 1974).

e. Accidental deaths and injuries from the transportation of coal are estimated to be proportional to train freight miles. In 1973, there were 1910 accidental passenger deaths for 770 million freight train miles (U.S. Nuclear Regulatory Commission, The Environmental Effects of Using Coal for Generating Electricity, prepared by Argonne National Laboratory, Chicago, Illinois: 1977.). A mix of 40 percent unit trains carrying each 10,000 tons of coal and 60 percent mixed trains carrying each 1,000 tons are projected for the year 2000 (derived from MITRE Corp., Accidents and Events). Current ratio is about 67 percent mixed trains. Average trip for a mixed train is estimated as 450 miles for the year 2000 (present estimate is 300 miles, longer trips are expected as Western coal supplies are expected to grow). Average round-trip for a unit train is 900 miles. Transporting a milition tons of coal involves 600 mixed trains $\times 450$ miles plus 40 unit trains $x 900$ or 306,000 freight miles which are associated with 0.76 passenger deaths. Assuming a ratio of 145 occupational deaths to 1300 general public deaths (derived from Baldewicz, 1974 for accidential deaths during 1968-1972), we obtain 0.084 occupational. accidental deaths per million tons of coal. A ratio between accidental injuries to deaths is derived from Baldewicz, 1974. During 1968-1972, there were 18,640 injuries and 1445 deaths. Hence we obtain 9.8 general public and 1.08 occupational injuries per million tons of coal.

f. Occupational accidental deaths and injuries for transporting a million barrels of oil are estimated as $3.8 \times 10^{-4}$ and $2.4 \times 10^{-2}$ (MITRE Corporation, Annual Environmental Analys is Report, vol. 1, prepared for the U.S. Energy Research and Development Adminiștration (ERDA), Report No. MTR-7627, Wașhington, D.C.: September 1977.) for pipeline distribution.: Ship tankers rates are estimated as $4.9 \times .10^{-3}$ deaths and $4.3 \times 10^{-2}$ injuries per milition barrels, for 42 percent $0 . i 1$ imports projected by the year 2000 (U.S. Executive Office of the President, National Energy Plan, Aprif:1977.) : 
g. Accidental deaths and injuries from conversion are those associated with construction of the facilities and with their operation. Construction deaths are estimated from the number of man-years that are required to construct the facilities. (See Table 1) and the risk estimates for the construction industry (i.e., 74 deaths per $10^{5}$ man-years and 15 disabling but non-fatal injuries per $10^{6}$ man-hours National Safety Council. Accidents Facts, Chicago: 1974). The annual increment is calculated by dividing the numbers by the 30 years life of facilities. Operational deaths and injuries are obtained from Radian Corporation, The Coal Resource System.

h. Derived from BNL, 1978.

i. Excess cancer risk of $1.55 \times 10^{-4}$ deaths/man year and $1.97 \times 10^{-4}$ deaths/ man year were estimated for coal gasification and for coal liquefaction plants (Salmon, 1978). Multiplying this risk factor by the number of workers of conversion plants (Table 1) provides the excess cancer risk per plant year.

j. Disease deaths to the general public are estimated as 0.68 per 1000 tons of $\mathrm{SO}_{2}$ emissions (derived from Ramsay, 1978).

k. Pipeline distribution is assumed.

1. Emissions of $\mathrm{SO}_{2}$ from the various energy systems are applied from Table 1.

m. Asthma aggravation is assumed as 0 to 980 cases per 1,000 tons of $\mathrm{SO}_{2}$ (derived from Ramsay, 1978.). 
Rail transport of coal is an important source of deaths and injuries at grade crossings to the general public. Comprehensive statistical data exist, but only in respect to general rail freight accidents and without implication to type of cargo. The apportioning of the data to coal transport is done by multiplying the total number of accidents by coal's share of the market expressed either in ton-miles or in miles of rail cargos. The two estimates can vary by about an order of magnitude. Safety risks of construction workers are available. These are multiplied by the number of estimated man-days needed to construct certain energy facilities to derive the expected rates of deaths and injuries associated with the construction phase. The uncertainties involved in the calculations are partly due to lack of information concerning manpower needs for construction of new types of energy facilities.

More serious errors are involved in attempting to estimate the rates of delayed deaths and disabilities from various lung diseases associated with coal mining. There is confusion when it comes to distinguishing between reportings of coal workers pneumoconiosis (CWP), which is a medically distinct disease caused by inhalation of coal mine dust, and black lung disease, which is only a legally defined disease consisting of several pulmonary disorders with a less clear relation to coal dust. Projection of CWP rates depends on estimating the ratio of surface to underground mining, the regional distribution of future mines, and the amounts of coal dust counts in mine and surface air. Although a significant decline in the occurrence of new cases of CWP is expected in the future because of dust suppression in mines and a contining shift to surface mining, it is doubtful whether the number of reportable cases of the disease will decline in the near future. This is because of the existing confusion in distinguishing between reported cases of CWP and black lung disease, which is expected to continue in the future and does not depend on coal dust measurements. Also, CWP incidence is related to exposures that have taken place a long time ago rather than recent 
exposures. There is an average delay of 14 years between the beginning of exposure to coal mine dust and the appearance of clinical symptoms (NAS, 1976). 01d cases of CWP will thus continue to surface for many years to come, even if new exposures to coal dust can be controlled.

The least reliable of the data are those applied to delayed deaths and damages to health of the general public from emissions of combustion products. The information is deficient in respect to estimation of the kinds and quantities of potential emissions and their environmental transport, the resulting exposures and categories of individuals among the exposed population; the expected dose-response relationships, and the complications that arise when exposure to a combination of pollutants takes place. Only associations rather than cause-and-effect relations exist between pollution and impacts. Thus, the establishment of doseresponse relations between significant effects and low levels of pollutants expected in the environment from coal technologies is very difficult. The active agent (or agents) that may cause adverse effects from emissions of combustion products is not established. Some of the active pollutants may well be new and more toxic conversion or transformation products produced in the atmosphere by complex photochemical reactions from the original air emissions and reactive chemicals in air. Identifying an adverse effect and attributing it to a pollutant, or to a combination of them, has a considerable judgmental component (Ferris, 1978). Added to these difficulties is the lack of sufficient information on the environmental persistence and dispersion of the polluants and the exposure distribution of involved persons. Models are often developed to estimate the dispersion and conversion of various pollutants, the expected dosages to specified populations, and their responses to the exposures. Such estimates are only indicative of the health impacts and include great uncertainties. 
Based on present knowledge, the main occupational health and safety impacts are those associated with coal mining, accounting for a predominant fraction of occupational deaths, injuries, and damages to health of the various coal systems. Their share, according to Table 3 varies from 69 to 97 percent of deaths and 69 to 90 percent of injuries and damages to health.

The most significant coal mining impact is from CWP, one of several respiratory diseases aggregated under the legal definition of black lung disease, which includes chronic bronchitis, CWP, and several obstructive aimay diseases. Although the prevalence of chronic bronchitis or of obstructive airway diseases is estimated to be almost three times greater among coal miners than CWP (derived from National Institute for Occupational Safety and Health (NIOSH), 1977 ), only (WP data appear in Table 3.

Prevalence of CWP increases in direct relation to exposures to coal dust, with considerably greater prevalence among underground coal miners than among surface miners. Control of respirable coal dust levels in mines is the most effective means of reducing the number of new CWP cases. This conclusion is supported by the British experience of limiting coal dust levels to $2 \mathrm{mg} / \mathrm{m}^{3}$ of air. Prevalence of CWP among British underground miners has dropped to 3 percent of the work force, who stiow only mild symptoms of the disease. 
Estimates of the prevalence of CWP vary widely among the reporting sources. According to NIOSH, between 10 and 15 percent of underground coal miners have some category of the disease (NIOSH, 1977). The Committee on Mineral Resources and the Environment of the National Academy of Sciences estimates the prevalence of the disease to be considerably higher, and to involve nearly 30 percent of underground miners (NAS, 1976).

Projections of future rates of CWP are uncertain. A significant decline of the disease can be expected if respirable dust controls specified in the Federal Coal Mine Health and Safety Act of 1969 and 1977 are rigidly implemented. However, for a long time to come, continued observance of CWP cases caused by past exposures to coal dust is expected because the disease has a delay time averaging 14 years, and another 10 or more years elapse before death (NAS, 1976). Furthermore, it is unsafe to generalize from the British experience concerning the impact of dust controls on the prevalence of CWP, because environmental and personal factors seem to play an important role in the prevalence of the disease, and they are expected to be different in the U.S. compared to Britain.

The annual estimate of the range of prevalence of CWP in Table 3 is based on the values of reported rates made by NIOSH (NIOSH, 1977). The higher value in the range of projected CWP rates is for a coal supply with 45 percent of the coal coming from underground mining (present mix). The lower value is for a projected mix of coal mining expected by the year 2000, when 90 percent of the coal supply is projected to come from surface mining. The same assumptions about the mix of surface to underground mining are also used in this table. to produce a range in the estimates of mining accidents.

Projected deaths from CWP are based on an average annual rate: of 1243 reportable deaths, applying to the period 1949-1969 (Baldewicz, 1974). Average annual underground coal mining during this period was 475 million tons (derived for the period 1949-1969 from Coal Data, 1976 (National Coal Association, 1977)). 
Mining of coal is the largest source of accidental deaths and injuries among occupational workers associated with any of the various coal energy systems. Accident rates per million tons of coal mined are closely associated with mining productivity and with the inherent safety risks per unit of coal output. Underground coal mining is more risky, than surface mining because of lower inherent safety $(0.48$ death and 37.11 injuries per million man-hours during 1975 versus 0.35 and 18.20 for surface mining) and because of smaller output per man-day (9.54 tons in 1975 versus 26.69 for surface mining, all numbers from Coal Facts, 1978-1979). The combination of these factors makes surface coal mining about four times safer in respect to accidental deaths associated with mining a million tons of coal, and about six times safer in respect to injuries.

The least amount of adverse mining impacts are associated with coal conversion systems, which produce fuels for combustion. They are estimated to consume about 20 to 25 percent less coal than electrical power systems and about 60 to 90 percent less coal than corresponding coal conversion plants combined with generation of electricity. If regional distribution of coal energy facilities is taken into account, greater concentrations of coal conversion plants may be expected in the Western United States. They would consume mainly surface-mined coal. A greater concentration of electrical plants is expected in the Eastern and MidWestern regions, using a greater portion of underground coal. Under these assumptions, considerably larger occupational health impacts will result from electrical power plants than from coal conversion plants. For example, a shift to 90 -percent surface coal will reduce respiratory occupational health impacts of coal conversion plants to about a quarter and accidental mining impacts to about half of those associated with the present mix of 55 percent surface coal (Table 3 ). 
There are several other occupational health impacts associated with coal mining. In order of importance, they consist of accidental deaths and injuries from

- Construction and,operation of energy conversion facilities,

- Transportation of coal, and

- Coal preparation and storage.

There are also several conflicting epidemiological studies concerning excess stomach cancer rates among miners, or their wives, in comparison to the general population (Matolo, 1972; Creagan, 1974). The issue is whether the excess cancers are mainly due to increased occupational risks or to socioeconomic differences between the miners and control groups. Falk (1977) recommends continuing to seek better epidemiological evidence on which to act in the future.

An important concern regarding coal conversion, and particularly coal liquefaction, relates to the potential risks of cancer in occupational workers in conversion facilities. The concerns are based primarily on two types of studies:

- Epidemiologic studies indicating an increased risk of cancer to workers routinely exposed to the products of coal, such as workers in coal gas, coking, coal hydrogenation industries, street pavers, and asphaiters;

- Laboratory findings indicating potential carcinogenicity of various coal products to animals, bacteria, and cells.

A reported incidence of cancers among occupational workers in coal conversion plants has been published by Sexton (1960a, 196nb). His information pertains to a coal liquefaction pilot plant at Institute, 
West Virginia, that was in operation from 1952 until the mid-1950s. "Two hundred fifty-nine. men were employed and 300 tons per day of coal hydrogenation products were produced. Because of awareness of the cancer risks involved, an industrial hygiene program was conducted that included education in hygiene procedures such as the use of barrier cream and protective clothing, daily changes of all clothing, and daily inspection of the skin. Sexton (1960b) has reported that, between 1954 and 1959 , 42 cases of skin lesions, which were diagnosed as precursors of skin cancers, were treated. In addition, there were 11 probable and 5 verified skin cancers. These rates are 16 to 37 times greater than found in the population of the United States and of West Virginia.

Exposure periods of the men to the chemicals varied from several months to several years, with some of the workers having been exposed to similar chemicals in previous laboratory work. Spot checks conducted on workers during the operation of the plant indicated skin contamination despite the cleaning procedures and protective measures. Recommended industrial hygiene programs for new liquefaction plants are much improved over that practiced at the Institute, West Virginia, plant. A conclusion drawn from these data is that exposure to coal liquefaction products is associated with skin cancer. No correlation between exposure and incidence of skin cancer has been evaluated, and the data are not conclusive concerning the incidence of other kinds of cancer.

The important sources of exposure of occupational workers, in coal conversion facilities are as follows:

- Contamination of maintenance workers from contacts with organic matter on equipment and structures;

- Accidental releases and fugitive emissions during operation and maintenance of the conversion facilities,

- Preparation of wastes for dịsposal, and

- Handling of products and byproducts. 
Evaluation of the potential cancer risks to these workers is impractical at this stage. The data collected from bench and pilot plants are insufficient because emissions have not been characterized, and many processes and residuals are projected to change during commercialization. Improved control technologies are also expected and will affect the rates of emissions of hazardous pollutants.

It is possible, and important, to arrive at preliminary estimates of the upper levels of the carcinogenic risks by using available epidemiologic data from processes similar to coal conversion, such as gas retorts, and oil refining.

Although coke oven processes are not comparable to coal conversion 'facilities, data on coke oven workers is discussed here because there is little else available. Any estimates of risk levels associated with coke oven workers would be considerably greater than the risk associated with conversion processes. These estimates therefore will be above the estimated upper bound of risk for conversion processes. Coke oven and gas retort workers have been exposed to similar carcinogenic compounds as those expected from coal conversion facilities. This assumption is substantiated by several measurements of benzo-a-pyrene (BaP) and other PHMs in the atmospheres of coke ovens. The temperatures of coking range between $1200^{\circ} \mathrm{C}$ and $1400^{\circ} \mathrm{C}$ (NIOSH, 1973), which are similar to those of coal conversion $\left(800^{\circ} \mathrm{C}\right.$ to $1500^{\circ} \mathrm{C}$ (DOE-EPA, 1977)). This similarity of temperatures is important because the production of carcinogenic materials formed by carbonization of coal and the incidence of lung cancer of occupational workers have been found to increase with temperature up to $1500^{\circ} \mathrm{C}$ (NIOSH, 1973).

Although the substances in coal conversion and coking are similar, the potential exposures are very different. Coal conversion operations are continuous and contained, whereas coking is carried out in batches and containment is poor, with fugitive emissions much higher (orders of magnitude) than is expected in coal liquefaction plants. As a result, 
the rates of exposure of coke oven workers to potential carcinogens are expected to be considerably larger.

Another major difference between the exposures of occupational workers in coke oven and coal conversion plants is that the former are also exposed to $\mathrm{SO}_{2}$. In the case of conversion plants, coal combustion is expected to take place in "balanced draft" boilers, which provide good containment of combustion products. $\mathrm{SO}_{2}$ has been reported to have a synergistic effect on carcinogenicity as demonstrated experimentally (Laskin, 1970; Falk, 1977).

observed and expected deaths and standardized mortality ratios for selected causes of death among 2048 full-time coke oven workers from 1953 to 1961 were studied by Lloyd (1971). He found that, for the total population of coke oven workers, excess mortality rates from cancer were accounted wholly by excess respiratory cancers. The risk of death from such cancers for all coke oven occupational workers was 2.5 times that of the expected rate. The risk for men employed at top-side jobs involving greater exposures to organic contaminants was 6.5 times greater than for men employed only at the side oven (standard mortality rate (SMR) of 818 versus 125). The excess mortality rates of side oven workers from a 11 other causes of death did not differ from expectation.

Two excess respiratory cancer deaths were observed by Lloyd (1971) among side coke oven workers for 12,880 man-years of work, or $1.55 \times 10^{-4}$ excess cancer deaths per man-year. Applying this rate to the estimated 320 to 780 workers of unit coal gasification plants (Table 1), an excess risk of cancer deaths of 0.050 to 0.12 per plant year is obtained. In the case of coal liquefaction plants, the excess cancer risk of $4.2 \times 10^{-5}$ per man-year for refinery workers* (Salmon, 1978) was added to the excess

* Based on a study in 1977 that observed 19 deaths versus 17.3 expected from malignant neoplasms of the genital organs and 24 observed versus 19.7 expected for malignant lymphomas. The study included 17 refineries, 19,800 occupational workers, and 142,650 man-years of work (19621971). 
risk of $1.55 \times 10^{-4}$ for coke ovens, yielding a combined excess risk of $1.97 \times 10^{-4}$ per man-year. Multiplying this number by 1300 to 1500 estimated workers of unit coal liquefaction plants (Table 1) gives an excess risk of cancer deaths of 0.26 to 0.30 per plant year. Estimates of the actual risks are that they are probably lower by a factor of 10 or more from those calculated; this is based on the much lower expected exposure rates in coal conversion plants and assumes a linear relationship between dose and effect. In any case, the figures so obtained are small relative to the other occupational health risks.

The same or even greater uncertainties that characterize the carcinogenicity risks of coal conversion apply to mutagenicity. Preliminary findings (Russell, 1978) indicate that the risks may be small. The same recommendations as those applying to carcinogens are indicated: further identification of the sources and chemical species and development of monitoring and protective programs.

HEALTH AND SAFETY IMPACTS TO THE GENERAL PUBLIC

The major categories of health and safety impacts to the general public from the various coal energy systems are as follows:

- Delayed deaths and disabilities from respiratory diseases associated with inhalation of pollutants, including air emissions from combustion processes and their transformation products produced during the air transport of the pollutants;

- Accidental deaths and injuries associated with the transporation of coal; and

- Delayed deaths and disablements from disease that may be associated with the leaching and migration into water and entry into food chains of trace mineral and organic contaminants from coal and from coal conversion processes. Better data, however, are needed to assess the extent of such contamination before drawing conclusions about its importance. 
Health Effects of Gases and Aerosols

With present knowledge, it is impractical to attempt an assessment of the health impacts of each pollutant that has been considered as a potential cause of adverse health effects. An index pollutant is selected, and the potential health impacts are calculated from this exposure. The rates of emission of the pollutant chosen as an index are usually derived from assumptions concerning the characteristics of the energy plant, fuel, and emission-control equipment. An air pollution model is then developed to take into account the transport of the index pollutant, atmospheric reactions, dosages to specified populations, and their responses to the doses. Errors are associated with each one of these assumptions, leading to large uncertainties and to broad ranges of estimated impacts.

Usually $\mathrm{SO}_{2}$, its sulfate equivalent, or particulate air pollution have been used as an index pollutant. Gaseous $\mathrm{SO}_{2}$, particulates, and small amounts of sulfate particulates $\left(\mathrm{SO}_{4}\right)$ are emitted mainly from coal combustion processes. Most of the sulfate particulates, however, are derived from $\mathrm{SO}_{2}$ conversion in air to $\mathrm{SO}_{4}$; photochemical and other reactions may proceed further, to sulfuric acid. The process is highly dependent on humidity, temperature, the $\mathrm{pH}$ of the aerosol, and the types and quantities of trace elements present that act as catalysts for the reactions.

The emission of nitrogen oxides also undergoes atmospheric reactions similar to those of $\mathrm{SO}_{2}$. In the presence of hydrocarbons, the oxides of nitrogen are photochemically oxidized to nitrities, nitrates, and nitric acid.

The bulk of the particulate matter emitted from the combustion of fossil fuels is nonrespirable (i.e., larger than $2.5 \mu \mathrm{m}$ diameter). The health and environmental impacts are mainly associated with the submicron particulate emissions, which are respirable. They also account for a greater portion of the atmospheric interactions that yield the sulfates and nitrates. 
Stationary sources of fossil fuel combustion are the major sources of oxides of sulfur and: nitrogen and of particulate emissions. It has been estimated that, in. 1975, stationary combustion contributed $22.1 \times$ $10^{6}$ tons of $\mathrm{SO}_{x}(62.6$ percent of total emissions from natural and human sources); $11.0 \times 10^{6}$ tons of $\mathrm{NO}_{x}$ (44.4 percent of man-made emissions); and $7.1 \times 10^{6}$ tons of particulates (20.2 percent of man-made emissions) (DOE-EPA, 1977). It is anticipated that fossil fuels, and particularly coal, will continue to be the major sources of $\mathrm{SO}_{2}$ emissions even if the BACT prescribed by New Source Performance Standards (NSPS) is applied to new sources.. It is therefore important to evalute and take advantage of new technologies such as coal conversion, which promises to reduce the emissions.

The sources of data concerning the health effects of air pollutants are derived either from laboratory studies of animals, studies of occupational groups, or epidemiological surveys of the general population. It is advantageous to combine information from all three kinds of studies, because each has limitations. Together they complement each other.

Animal studies provide information on the mechanisms of the effects of different pollutants. Extrapolations of other kinds of information to man are limited by physiological differences between species.

Studies of occupational exposures provide valuable information on levels of pollutions in air and the corresponding exposures, body burdens, and elimination rates of the pollutants. The applicability of the information to the general public is limited because the conditions of exposure and susceptibility are different. Occupational exposures usually take place in different environmental conditions of temperature and humidity, exposure times, and durations than those of the general public. Usually, if an effect can be demonstrated from a study of occupational workers, an effect should be sought in the general population.

Epidemiologic studies of the general population complement animal and occupational investigations. However, there are limitations with respect to estimating the dose, measuring the effects, and correcting for 
variations in environmental, socioeconomic, and racial composition of the exposed individuals. Serious problems of interpretation are often caused by competing risks, such as cigarette smoking, which can completely mask the effects of chronic exposures to low levels: of air pollution (Ferris, 1978).

Estimates of expected deaths and illnesses from the combustion and transformation products of coal vary greatly among different authors. The variations are as much as two orders of magnitude, or even more and reflect the large uncertainties involved in the assessments.

Correlations between high levels of $\mathrm{SO}_{2}$, excess mortality, chronic respiratory illnesses and aggravation of symptoms of emphysema, asthma, bronchitis, and various cardiovascular symptoms are reported in several studies by Ferris (1978) and observed during acute episodes of air pollution. Ferris also critically reviewed the various studies on health effects of exposures to. low levels of regulated air pollutants. He considered it unreasonable to conclude that the commonly occurring levels of sulfur oxides that are now measured can have an effect on mortality. Nor could he find proof of excess mortality from the other air pollutants at their usual environmental levels.

Ramsay (1978) has compared the various model calculations available in the literature that estimate the adverse health impacts of air pollution emissions from coal power plants on adults and children. He used emissions of sulfur oxides as an index of impacts from all the air pollutants derived from power plants. His reported range of impact values is used in Table 3 to derive the estimates of health impacts from air pollutants associated with electricity generation and coal conversion. The ranges of estimated health impacts are

- 0 to 0.68 deaths per 1000 tons of $\mathrm{SO}_{2}$ emissions and

- 0 to 980 cases of aggravation of asthma per 1000 tons of $\mathrm{SO}_{2}$ emissions.

The lower value of zero is chosen to reflect the large uncertainties involved in the assessments and to indicate the considerable judgmental value involved. 
Impact from Coal Transportation

The transportation of coal is the other major source of potential health impacts to the general public. The transportation of coal by freight trains accounts for about two-thirds of all present coal transportation and is expected to retain its dominance in the future. As an approximation of the potential deaths and injuries from coal transportation, those attributed only to the portion of coal that is carried by railroads are considered.

The data available on accidental deaths and injuries from rail transport of coal are aggregated with those for all other goods carried by railroads. Coal's share of the impacts is apportioned from the data on the basis of miles traveled by coal-carrying trains. The present average haul distance is estimated as $300 \mathrm{miles}$, increasing to $450 \mathrm{miles}$ by the year 2000. A mix of 60 percent mixed trains carrying 1,000 tons of coal and 40 percent unit trains carrying 10,000 tons are assumed (Table 3, footnote e). It is estimated that 60 percent of the coal will be transported by rail. This is the projected rate for the year 2000 (Mitre, 1977); the present share of railways is about 66 percent. The rates applied to estimate the general public potential impacts from transportation per million tons of coal are 0.76 deaths and 9.8 injuries .

The distribution of accidental deaths and injuries from coal transportation is related to coal consumption. The distribution of impacts among different energy systems is similar to that of occupational health impacts, with the smallest impacts associated with coal conversion-combustion systems. Greater concentration of coal conversion plants in the West will further reduce the potential general public health impacts from both combustion products and from transportation relative to coal-electricity systems. The effect is due to smaller population density, smaller backgrounds of pollutants and shorter transportation distances for Western plants. 
Impacts from Trace Contaminants

There is concern about potential health impacts to the general public from various trace elements found in coal or from trace chemicals. produced during coal combustion or conversion. Some of the potential effects include carcinogenicity and genetic damage.

The trace elements of concern that are found in coal include arsenic, cadmium, chromium, lead, mercury, nickel, the radionuclides uranium and thorium, and various associated radioactive decay products. These contaminants can reach the environment either before, during, or after coal combustion or conversion. The routes of entry of the contaminants into the human body are through inhalation of contaminated air or through ingestion of contaminated water or food. The main sources of human exposure include runoff and seepage from coal mining and storage coal waste piles, air emissions from fires of coal and.waste storage piles, and the combustion of coal or its products.

The organic chemicals of concern that are formed during:the combustion or conversion of coal are the polynuclear hydrocarbons discussed in the previous section of this report. Environmental contamination can occur from air emissions during normal coal. combustion and conversion processes, accidental and fugitive emissions during the operation or maintenance of electricity generation or coal conversion facilities, runoff and seepage from waste management and storage operations, pollutants associated with the distribution and utilization of liquid fuels produced from coal conversion processes, and contamination from utilization of solid waste byproducts for landfills and as soil conditioners. Contamination from many of these sources can be controlled by containment of the wastes of the various coal combustion and conversion processes, and utilization of control technologies to reduce environmental. pollution.

There is insufficient knowledge to quantify, or even to fully evaluate, the potential health impacts from trace contaminant"s: $i_{0} 0$ niy 
limited information is available on potential air emissions and the resulting human intakes of trace contaminants from coal energy systems. Information about potential environmental pollution and exposures associated with contamination of water supplies and agricultural products from runoff and seepage waters is practically nonexistent. Further complications in the evaluation of health impacts, particularly carcinogenicity, arise because they depend not only on levels of exposure to trace contaminants. Carcinogenicity may depend on complicated interactions among carcinogens, co-carcinogens, initiators, and various other environmental agents and components. The risk depends also on the chemical structure of trace contaminants, their physical forms, and portals of entry into the body. Many of the trace contaminants will be changed during their environmental transfer by chemical and physical processes and by reacting with the constituents of the environment to produce different products under different conditions. As a result, characterization of the emitted pollutants is not sufficient for estimating the potential impacts. Further research is needed on the environmental transformation processes and the exposures of sensitive organ targets to the transformation products.

Preliminary estimates of the potential health impacts from emissions of polynuclear and aromatic hydrocarbons from coal combustion and conversion processes can be made by using BaP or benzene soluble organics (BSO) as surrogates. BaP and BSO emissions and atmospheric concentrations have been reported (Newkind, 1976; Suta, 1977), and relatively good correlations observed between their atmospheric concentrations and those of various polynuclear aromatic compounds (Suta, 1977). The health impacts from polynuclear aromatic hydrocarbons from coal, coal combustion, and conversion may be estimated by comparing the BaP exposures and associated health risks with those of coke oven workers.

Coke ovens are one of the major sources of BaP emission, accounting in 1972 for 170 tons of emissions or about 20 percent of the nationwide BaP emissions from all sources (Suta, 1977). About 15 million people who live in regions surrounding coking plants in the United States are 
exposed to coke oven emissions. The excess mortality and morbidity risks among coke oven workers have been estimated in several epidemiologic studies (Lloyd, 1971; Redmond, 1972; Mazumdar, 1975). The cancer risks to the population living near coke oven or gas works have been estimated by extrapolation* from the data of excess cancer incidence and exposures to BaP and B.SO of coke oven workers (EPA, 1978). The total number of excess lung cancer deaths is estimated at about 150 cases per year for the 15 million people exposed to coke oven emissions. There were, in 1976, about 150 equivalent coal power plants $* \star$ operating at 1000 MWe at 75 percent load factor in the United States. These plants emitted only about 0.5 percent of BaP emissions of coke oven plants, so the excess annual cancer death risks associated with a 1000-MWe coal electric power plant may be estimated to be about 0.005 .

The main sources of exposure to trace elements are smelters, incinerators, industrial processes, and automobiles. There are also intakes through food and water, due largely to weathering and industrial pollution. Emissions from coal combustion in power plants are not considered to be an important source of trace element exposure (Falk, 1977; ERDA, 1977; and Congressional Record, 1978).

The conclusion about public exposures to trace mineral and organic contaminants from coal conversion energy systems is that they will not present increments of risk that will challenge the environmental accept-

* The estimates of excess cancer risks to the general public are based on linear, non-threshold dose reponse assumptions. The exposures of people living in the vicinity of coke plants are estimated to be about two orders of magnitude lower than for lightly exposed workers. No significant excess cancer incidence has been observed among occupational workers at these lower levels of exposure. The estimates are therefore regarded as crude and probably on the high side:

** The number is obtained by dividing the total annual electricity production in kilowatthours in the United States during 1976 by (1000 MWe $)(1000 \mathrm{~kW} / \mathrm{MW})(0.75)(365)(24)=6.57 \times 10^{9}$. 
ability of these technologies. Even if coal conversion plants have emissions larger than those of equivalent power plants, their expected locations in low-density population areas will reduce the potential exposures. However, more information concerning emissions, exposures, and potential health impacts of trace contaminants is needed to confirm this preliminary conclusion. Special attention is drawn to water and food contamination with trace elements from water, runoff and seepage from solid wastes, which are expected to include the bulk of the trace elements. Evaluation of the potential exposures from these sources is needed.

COMPARISON OF THE HEALTH IMPACTS FROM VARIOUS SYSTEMS

The occupational health impacts associated with the mining of coal are the predominant ones, and mask all others. Because mining impacts depend mainly on the overall energy efficiencies of the coal systems, the smallest impacts of conversion technologies are associated with the direct use of low-Btu gasification (overall efficiency is 49 percent). The largest impacts are associated with the use of liquid products from coal conversion for electricity generation (efficiency is 22 percent).

Coal conversion technologies that convert the fuels to electricity have larger impacts than the corresponding plants with direct fuel uses. The occupational health impacts from the latter type of plants are about twice as large as those from corresponding plants because of greater consumption of coal and greater emissions of pollutants. Conversion technologies that involve direct utilization of the fuels produced by them manifest smaller occupational health impacts than electrical power plants.

The key public health impacts from the various coal systems are those from emissions of combustion products and from coal transportation. The health impacts to the general public from coal conversion systems are considerably smaller than from an equivalent coal-electric system, the main reason being that most of the health impacts from environmental pollutants are associated with combustion products. Only about 10 percent 
of the coal undergoes combustion in coal conversion processes, and the synthetic fuels produced are cleaned of sulfur prior to utilization. For coal gasification, the sulfur is removed almost entirely in conversion and the later combustion of the gas emits very little sulfur. For coal liquefaction, some sulfur still remains in the coal liquids and is later emitted upon combustion. The results of these system-wide emissions are reflected in Table 1.

Thus, considerably smaller releases of $\mathrm{SO}_{2}$ are emitted from coal conversion systems than from coal-electricity. This advantage is partly offset by the fact that synthetic oil and gas are burned closer to the public than coal in electric power plants. But there is not an equivalent amount of pollutant emissions released. Accidental deaths and injuries to the general public are also smaller for coal conversion systems because of their higher cverall energy efficiencies. 


\section{ENVIRONMENTAL IMPACTS}

The most significant potential regional impacts are those from dry and wet depositions of gaseous and particulate pollutants, transformation products from the combustion of fossil fuels, and thermal pollution from energy parks. The most important pollutants from the combustion of fossil fuels are sulfur oxides and sulfates, particulate matter, photochemical oxidants, nitrogen dioxide, and nitrates. The major environmental impacts from dry and wet depositions of these pollutants are depletion of nutrients from soils or aquatic systems, inactivation of important soil micro-organisms, and decreases in yields of various plant and animal species due to a combination of direct damages and indirect changes in environmental conditions.

The most susceptible receptors of these pollutants are plants, particularly higher plants and trees growing in high-altitude forests. Some species of fish, for example, trouts and salmon, are also sensitive. Animals, in general, are about an order of magnitude less sensitive to the depositions than plants. Indirect changes affecting specific plant and animal species and changes affecting whole ecosystems should be considered. Usually, stress on one component of an ecosystem will manifest itself through changes in other components because of the interdependence of the ecosystems. Ecological changes may be difficult to follow because they are sometimes removed in space or time from the original source of stress.

Other major environmental impacts on the welfare of man are decreases in agricultural and forest yields, decreases in freshwater fish production, corrosion or deterioration of materials such as steel and paints, and decreases in visibility.

The environmental impacts can be evaluated separately for, each one of the pollutants, but for the same reasons outlined in the section on health impacts, it is common to be concerned about the combined effects. The major components are again the oxides of sulfur and nitrogen and their transformation products. Photochemical oxidants, particularly ozone and 
peroxyacylnitrates (PANs), play a particularly important role in causing damages to plants. The regional environmental impacts from fossil fuel combustion are derived from the many sources of combustion within an area of thousands of square miles because the products can be transported for hundreds of miles. Sulfur oxides, particulates, or sulfates are used as indicators of the potential impacts from the various pollutants. In this report, $\mathrm{SO}_{2}$ is used as the indicator.

LOCAL IMPACTS

Acidic mine drainage from eastern coal mines and increased salinity of surface and ground waters in the vicinity of western coal fields are the most significant ecological local impacts from coal mining. This acidic or alkaline mine drainage can alter both size and species composition of aquatic ecosystems. Control includes sealing of the mine, which needs to be maintained every few years, and/or neutralization of the discharges, but is very difficult, particularly in the case of acid drainage from abandoned underground mines.

- Another local impact for coal mining is subsidence, the settling of ground surface near underground mines to occupy voids remaining after coal extraction. Control of subsidence is very difficult, requiring either that more coal is left in place to support the surface (about 50 percent), or that the subsidence is hastened under planned conditions.

The high erosion rate of the exposed overburden by surface mining can lead to loss in plant yields, destruction of wildlife habitats, and. disruption of present land uses. Erosion can also cause increased sediment loading in streams and impacts on ground water tables. Revege-. tation, mulching, and slope reduction are practiced to achieve runoff control. Land reclamation, restoration of both surface mining. and the surface effects of underground mining, is required by the new 1977 Federal Surface Mining Act. However, returning the soil to the original contour or to agricultural land may not always work or be practical, and 
there may be conflicts between scarce water resources in the West and the need for water for reclamation.

The generation of solid wastes per coal plant is expected to increase because of flue gas desulfurization sludges. Potential adverse consequences of disposal are the diversion of land from other uses and the contamination of ground and surface waters.

COMPARISON OF THE IMPACTS FROM ALTERNATIVE COAL SYSTEMS

The major global environmental impact from coal energy systems is potential weather modification because of $\mathrm{CO}_{2}$ emissions. Conversioncombustion systems emit about one-third to half of the $\mathrm{CO}_{2}$ emitted by coal-electric systems and about half of the emissions of conversionelectricity systems.

The main regional environmental impacts and damages to property and agriculture are associated with dry and wet depositions of combustion and transformation products. They are proportional to $\mathrm{SO}_{2}$ emissions. Three to four times more releases of $\mathrm{SO}_{2}$ are expected from coal electricity generation unit systems than from coal conversion systems; two to three times more emissions are estimated from coal conversion combined with electricity generation unit systems.

The main local environmental impacts from the various coal systems are (a) damages and disturbances to property and land users; agriculture, plants, animals, and ecosystems associated with land disturbed or subsided from mining, acid mine drainage, and the disposal of solid wastes and (b) the effects of combustion and conversion products from electricity generation, coal conversion, and utilization of synthetic liquid fuels. The land impacts are mainly determined by the amounts of coal needed to produce a unit of useful energy of the various coal systems. The concliusion is that the smallest local impacts will be associated with coal conversion technologies that produce fuels for direct combustion. The largest impacts are estimated from coal conversion to electricity systems that use about double the coal of corresponding systems with combustion of fuels. 
These conclusions can be modified by factors of location and scale of operations. Coal conversion plants are expected to be three to six times larger than electrical power plants and may require larger coal mines to support them. In addition, coal conversion plants are expected to be concentrated in the Western parts of the country and will rely more on surface-mined coal, resulting in fewer acid mine drainage impacts. 
Baldewicz, W., et al., 1974, Historical Perspectives on Risk for Large Scale Technological Systems, UCLA-ENG-7485, University of California, Los Angeles, California.

Brookhaven National Laboratory, 1975, Sourcebook for Energy Assessment; $B N L-50483$, M. Beller, editor.

Brookhaven National Laboratory, 1978, Energy System Network Simulator, Sevian, W.A. and P.D. Moskowitz, Biomedical and Environmental Assessment Division.

Carasso, M., et al., 1975, The Energy Supply Planning Model, Vol. 1, Bechtel Corp., San Francisco, California.

Congressional Record, January 16, 1978, Report of Presidential Commission.

Council of Environmental Quality, 1975, Energy Alternatives: A Competitive Analysis, Washington, D.C.

Creagan, E.T., et al.., 1974, "Mortality from Stomach Cancer in Coal Mining Regions," Archives of Énvironmental Health, Vol. 28, pp. 28-30.

Department of Energy-Environmental Protection Agency, 1977, Energy/Environmental Fact Book, EPA 600/9-77-041, Decision Series.

Department of Energy, 1978, Technology Characterization Documents on Coal Gasification and on Coal Liquefaction (draft), Division of Technology Assessment, Office of Assistant Secretary of Environment.

Energy Research and Development Administration, 1974, Comparative Risk-Cost Bene-Study of Alternative Sources of Electrical Energy, WASH-1224.

Energy Research and Development Administration, 1977, Fossil Energy Technical Program Summary Book.

Environmental Protection Agency, 1978, Carcinogenic Assessment Group, Preliminary Report on Population Risk to Ambient Coke Oven Exposures, Roy E. Albert, Chairman.

Falk, Hans L., 1977, Health Effects of Coal Mining and Combustion: Carcinogens and Cofactors (Draft), Paper No. 7 prepared for President's Committee on Health and Ecological Effects of Increased. Coal Utilization. 
Ferris, Benjamin G., 1978, "Health Effects of Exposure to Low Levels of Regulated Air Pollutants: A Critical-Review," Journal of the Air Pollutant Control Association, Vol. 28, No. 5, pp. 482-487.

Laskin, S., et al., 1970, Studies in Pulmonary Carcinogenesis, AEC Symposium Series No. 18, M.G. Hanna et al., editors, Washington, D.C.

Lloyd, J.W., 1971, "Long-Term Mortality Study of Steelworkers V. Respiratory Cancer in Coke Plant Workers," J. Occup. Med., Vol. 13, No. 2, pp. 53-57.

Matolo, N.M., et al., 1972, "High Incidence of Gastric Carcinoma in a Coal Mining Region," Cancer, Vol. 29, pp. 733-737.

Mazumdar, S., et al., 1975, "An Epidemiological Study of Exposure to Coal Tar Pitch Volatiles Among Coke Oven Workers," J. Air Pollution Control Assoc., Vol. ?5, No. 4, pp. 382-389.

Mitre Corp., 1977, Annual Environmental Analysis Report, MRT-7625, Vol. 1, prepared for the Energy Research and Development Administration.

National Academy of Sciences, 1976, Mineral Resources and the Environment. Supplementary Report: Coal Workers Pneumonconiosis Medical Considerations, Some Social Implications, prepared by COMRATE, Hashington, D.C.

National Academy of Sciences, 1975, Panel on Direct Combustion of Coal, Committee on Processing and Utilization of Fossil Fuels, Assessment of Advanced Technology for Direct Combustion of Coal, Washington, D.C.

National Academy of Sciences, 1978a, Ad Hoc Panel of Liquefaction of Coal, Committee on Processing and Utilization of Fossil Fuels, Assessment of Technology for the Liquefaction of Coal, 2 volumes, Washington, D.C.

National Academy of Sciences, 1978b, Panel on Low Btu Gasification of Coal, Assessment of Low and Intermediate Btu Gasification of Coal, Washington, D.C.

National Coal Association, 1977, Coal Data, 1976, Washington, D.C.

National Coal Association, 1978, Coal Facts 1978-1979, National Coal Association, Washington, D.C.

National Institute for Occupational Safety and Health, 1973, Criteria for a Recommended Standard: Occupational Exposure to coke Over Emissions, NIOSH, Cincinnati, Ohio. 
National Institute for Occupational Safety and Health, 1977a, Occupational Safety and Health Implications of Increased Coal Utilization. (Draft) Prepared for President's Committee on Health and Ecological Effects of Increased Coal Utilization, Washington, O.C.

Newkind, H.W., 1976, Environmental Effects of Energy Production and Utilization in the U.S. Volume 1: Sources, Trends and costs of Control, University of California, Lawrence Livermore Laboratory.

Oak Ridge National Laboratory, 1977, Environmental Health and Control Aspects of Coal Conversion: An Information Overview, Vol. 2 , ORNL/EIS-94.

Perry, Harry, 1972, Conservation of Energy, prepared by the Library of Congress, Congressional Research Service, for the Committee on Interior and Insular Affairs, U.S. Senate, 92nd Congress, Serial 2-18, 1972.

Perry, Harry, 1977, Introduction to Draft Report of President's Committee on Health Implications of Coal Gasification.

Radian Corp., 1976, The Coal Resource System, Final Draft.

Ramsay, William, 1978, Unpaid Costs of Electrical Energy: Health and Environmental Impacts from.Coal and Nuclear Power, Resources for the Future, Inc., Preliminary Manuscript, Washington, D.C.

Redmond, C.K., et al., 1972, "Long Term Mortality of Steel Workers: VI. Mortality from Malignant Neoplasms amona Coke Oven Workers," Journal of Occupational Medicine, Vol. 14, pp. 621-629.

Russell, W.L., 1978, Communcation During Review of Heaith and Environmental Implications of Various Energy Systems, RFF.

Salmon, E.J., 1978, Health and Environmental Implications of Various Energy Systems, draft report prepared for the National Energy Strategies Project, Resources for the Future, Washington, D.C.

Sexton, R.J., 1960a, "The Hazards to Health in the Hydrogenation of Coal: I. An Introductory Statement on General Information, Process Description, and a Definition of the Problem", Archives of Env. Health, Vo1. 1, pp. 181-186.

Sexton, R.J., 1960b, "The Hazards, to Health in the Hydrogenation of Coal: IV. "The Control Program and the Clinical Effects," Arc. Env. Health, Vol. 1, pp. 208-231.

Suta, Benjamin E., 1977, Human Population Exposures to Coke Oven Atmospheric Emissions, U.S. Environmental Protection Agency, Report No. 27. 
United Nations, 1977, Department of Economic and Social Affairs, Statistical Yearbook, 1976, New York.

U.S. Congress 1977, David Gates Before the Subcommittee on the Environment and the Atmosphere, Committee on Science and Technology, U.S. House of Representatives, Washington, D.C. 


\section{APPENDIX}

Structural Diagram of the Organization, Preparation, and Review of the Comparative Assessment of Health,

Safety, and Environmental Impacts of Coal Use

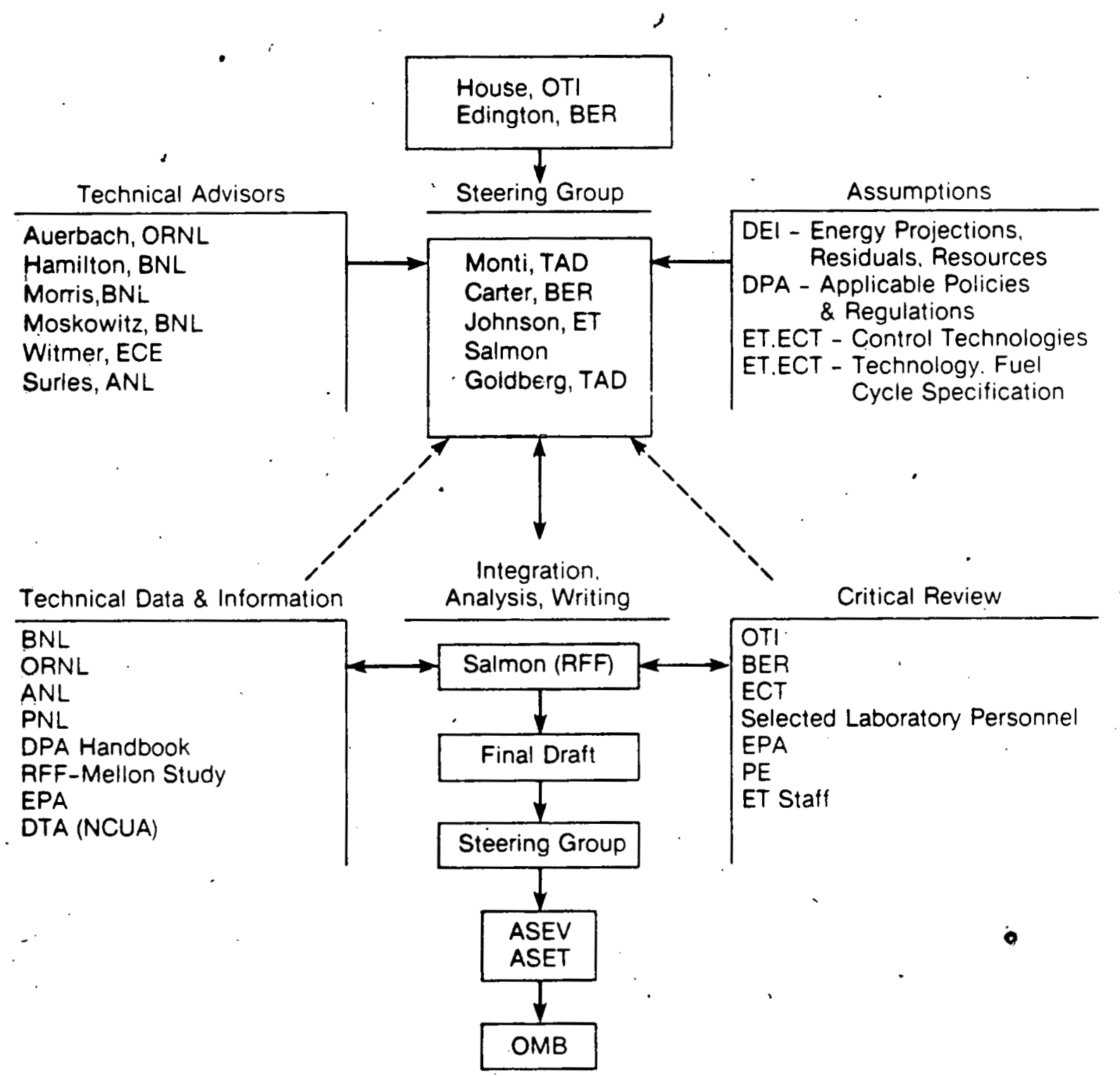

Source: Arnold Goldberg, DOE 


\section{United States}

Department of Energy

Washington, DC 20545

DOE-350

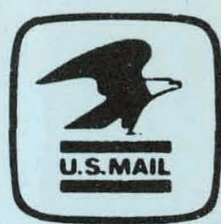

Official Business

Penalty for Private Use, $\$ 300$ 